\title{
Application of the HYSPLIT model for birch pollen modelling in Poland
}

\author{
Daria Bilińska-Prałat $(\mathbb{D} \cdot$ Małgorzata Werner • Maciej Kryza • Małgorzata Malkiewicz • \\ Piotr Rapiejko • Kazimiera Chłopek • Katarzyna Dąbrowska-Zapart • \\ Agnieszka Lipiec • Dariusz Jurkiewicz • Ewa Kalinowska • Barbara Majkowska-Wojciechowska • \\ Dorota Myszkowska • Krystyna Piotrowska-Weryszko • Małgorzata Puc • \\ Anna Rapiejko • Grzegorz Siergiejko • Elżbieta Weryszko-Chmielewska • \\ Andrzej Wieczorkiewicz • Monika Ziemianin
}

Received: 30 November 2020/Accepted: 22 December 2021 / Published online: 29 January 2022

(C) The Author(s) 2022

\begin{abstract}
In this work, the HYSPLIT model was used to reproduce birch pollen concentrations in Poland for the years 2015 and 2016, where there was significant variation in terms of pollen concentrations and start/end dates of the pollen season. The analysis of pollen observations showed that the seasonal pollen integral (SPIn) was low in 2015 with a shorter season compared to 2016. In 2016, SPIn was unusually high. The HYSPLIT model simulation, with a one-hour temporal resolution, was conducted during the birch
\end{abstract}

D. Bilińska-Prałat $(\bowtie) \cdot$ M. Werner $\cdot$ M. Kryza

Department of Climatology and Atmosphere Protection, University of Wroclaw, ul. Kosiby 8, 51-621 Wroclaw, Poland

e-mail: daria.bilinska@uwr.edu.pl

\section{Malkiewicz}

Laboratory of Paleobotany, Department of Stratigraphical Geology, Institute of Geological Sciences, University of Wroclaw, Wroclaw, Poland

P. Rapiejko · D. Jurkiewicz

Department of Otolaryngology With Division of CranioMaxillo-Facial Surgery, Military Institute of Medicine,

Warsaw, Poland

P. Rapiejko · E. Kalinowska · A. Rapiejko ·

A. Wieczorkiewicz

Allergen Research Center Ltd., Warsaw, Poland

K. Chłopek · K. Dąbrowska-Zapart

Faculty of Natural Sciences, Institute of Earth Sciences, University of Silesia in Katowice, , Katowice, Poland pollen season (from March to May) for 2015 and 2016. Meteorological data were obtained from the WRF model. The birch coverage map of the European Forest Institute was used. The emission, introduced to the model, covered Central Europe with a resolution of $0.3^{\circ} \times 0.3^{\circ}$. The results were compared to data from 11 observation stations in Poland. The measured birch pollen concentrations for 2015 were overestimated by HYSPLIT at 8 of the 11 stations (normalized mean bias/NMB from 0.13 to 2.53 ) and underestimated for
A. Lipiec
Department of Prevention of Environmental Hazards and Allergology, Medical University of Warsaw, Warsaw, Poland
B. Majkowska-Wojciechowska
Department of Immunology and Allergy, Medical
University of Lodz, Łódź, Poland
D. Myszkowska $\cdot$ M. Ziemianin
Department of Clinical and Environmental Allergology, Jagiellonian University Medical College, Kraków, Poland
K. Piotrowska-Weryszko · E. Weryszko-Chmielewska Department of Botany and Plant Physiology, University of Life Sciences in Lublin, Lublin, Poland
M. Puc
Institute of Marine and Environmental Sciences,
University of Szczecin, Szczecin, Poland
G. Siergiejko
Pediatrics, Gastroenterology and Allergology Department, University Children Hospital, Bialystok, Poland 
three stations (NMB from -0.44 to -0.15 ). For 2016, the model highly underestimated the pollen concentrations, with $\mathrm{NMB}$ ranging from -0.45 to -0.93 . In general, the results show that the model can resolve the main peaks of pollen concentrations, which is a step forward in the application of the HYSPLIT model for birch pollen forecasting over Poland. We suggest the application of methods that can reduce the bias of temperature such as meteorological data assimilation or bias correction, which could improve calculation of the start of emissions and consequently the start of the pollen season as well as pollen concentrations.

Keywords HYSPLIT $\cdot$ Pollen · Birch · Dispersion

\section{Introduction}

Birch trees release the largest amounts of pollen in western Europe (Clot, 2001; D'Amato \& Spieksma, 1992). These trees are very common in Poland (Myszkowska, 2013; Skjøth et al., 2008). According to Samoliński et al. (2014), almost $15 \%$ of the Polish population are sensitive to birch pollen following an evaluation of skin prick tests with birch pollen allergens in the biggest epidemiological study ever carried out in Poland. Even very low concentrations of pollen, amounting to 20 pollen $\mathrm{m}^{-3}$, can still cause allergic symptoms (Rapiejko et al., 2007).

The allergenic symptoms depend on pollen concentration (Rapiejko et al., 2007), whereas pollen concentration can vary greatly, depending on the vegetation's composition (Bilińska et al., 2019a, 2019b; Charalampopoulos et al., 2018; Myszkowska et al., 2010) and meteorology, i.e. temperature, wind speed, relative humidity (Kaszewski et al., 2008; Majeed et al., 2018; Puc et al., 2015). Previous studies have shown that even pollen stations located close to each other may differ significantly with regard to the amount of pollen (Bilińska et al., 2019a, 2019b). In this case, the modelling of pollen distribution is very important, especially for people allergic to it.

The number of studies on the application of chemical transport models for birch pollen modelling has increased in recent years. Zhang et al. (2014) have used the WRF-MEGAN-CMAQ modelling framework to simulate the variation in spatiotemporal patterns of tree pollen dispersion over southern California (USA). The measured birch pollen concentrations were low, but the model was able to simulate a peak in May (Zhang et al., 2014). Sofiev et al. (2015) ran a seven-model European ensemble of MACC-ENS to simulate birch pollen dispersion in Europe for 2013. The models were able to reproduce the timing of the season, usually within a few days from the observed start of the season, which was also the case for the end of the season (Sofiev et al., 2015). In aerobiology, the HYSPLIT model is mainly used as a trajectory model, for example, to show the source areas of pollen observed at a given station/location (Bilińska et al., 2017; Hernández-Ceballos et al., 2011; Stach et al., 2007; Veriankaite et al., 2010). The HYSPLIT model has also been used for pollen concentration modelling (Bogawski et al., 2019; Efstathiou et al., 2011; MayaManzano et al., 2021; Pasken \& Pietrowicz, 2005). Pasken and Pietrowicz (2005) used a combination of the MM5 and HYSPLIT models to generate a daily forecast of oak pollen concentration and found that the source-oriented method is promising for forecasting oak pollen. Efstathiou et al. (2011) used the CMAQ model and HYSPLIT model to compare the results of birch and ragweed pollen dispersion simulations for these two models. It showed comparable behaviour of pollen particles' dispersion by both models (Efstathiou et al., 2011). Bogawski et al. (2019) used the HYSPLIT model to investigate the movement of birch pollen emitted from potential source areas to detect long-distance transport (LDT) to Poland. They found that the main source of LDT of birch pollen to Rzeszów and Poznań is western Russia (Bogawski et al., 2019). Maya-Manzano et al. (2021) used the HYSPLIT model to calculate the 48-h backward footprints of birch pollen recorded in Dublin and Carlow for the main pollen season of 2018 and 2019. It was shown that the chance of having birch pollen level above 80 pollen grains $\mathrm{m}^{-3}$ is more likely when air masses are longer over Great Britain (Maya-Manzano et al., 2021).

The purpose of the study is to check the ability of the HYSPLIT dispersion model to reproduce birch pollen concentrations and season characteristics such as start/end of the pollen season and seasonal pollen integral (SPIn) for two different years (2015 and 2016). These years were chosen because they differ significantly in terms of total SPIn value or the season's duration. The HYSPLIT model has been 
mainly used so far to indicate the source areas of pollen grains with application of both trajectories and the dispersion mode. In our work, we use the model to calculate the dispersion of birch pollen for the whole season and to evaluate the results by comparing them with the observational data, which is a step forward in the application of HYSPLIT over Europe.

\section{Data and methods}

\subsection{Pollen sampling and the analysed seasons}

Birch pollen measurements were available from 11 sampling sites in Poland (Fig. 2). At all sites, pollen is gathered with the use of the Burkard trap and counted following the recommendations of the International Association for Aerobiology (Galán et al., 2014). Pollen grains were counted along four longitudinal transects under a light microscope with 400 magnifications. The pollen concentrations were expressed as the number of pollen grains per $\mathrm{m}^{3}$ of air as a daily mean value (pollen $\mathrm{m}^{-3}$ ) (Galán et al., 2017). The pollen season's characteristics were counted with the use of the 95\% method, which means that the pollen season starts when the pollen count reaches $2.5 \%$ of the annual pollen sum and ends when the annual pollen sum reaches 97.5\% (Andersen, 1991; Jato et al., 2006).

For our analysis, we have chosen the years 2015 and 2016, as they were characterized by divergent seasonal characteristics. In 2015, the annual pollen sum was low, compared to 2016, whereas in 2016 the annual pollen sum was several times higher than in 2015(Kubik-Komar et al., 2019; Myszkowska et al., 2021). Besides, the very high SPIn in 2016 at Białystok and Szczecin stations has been linked with cases of birch pollen long-distance transport (Puc et al., 2016). In this work, we have also run the HYSPLIT trajectory model to check whether such a situation could occur for Wrocław (see the chapter on the HYSPLIT backward trajectories below). The whole procces of the birch pollen modelling applied in this work is presented in Fig. 1.

\subsection{Meteorological data}

The meteorological data for the HYSPLIT model were calculated using the WRF model (version 3.9.1; Skamarock et al., 2008). The model domain covers
Europe at a $12 \mathrm{~km} \times 12 \mathrm{~km}$ grid (285 grid points in west-east and 332 in the north-south direction; polar stereographic projection). Vertically, the domain uses 35 levels. The boundary and initial conditions for the model were provided by the NCEP FNL Operational Analysis, with a horizontal resolution of $1^{\circ} \times 1^{\circ}$ and 27 vertical levels. The main physical options used in the WRF model include the Noah land surface (Chen \& Dudhia, 2001), Mellor-Yamada-Janjic scheme for boundary layer (Janjic, 2001), Morrison double-moment microphysics scheme and Grell 3D cumulus parameterisation (Grell, 2002). This choice of the main physical options was earlier evaluated in detail for the same simulation area by Kryza et al. (2017) and Ojrzyńska et al. (2017) for multiple years and various seasons. This suit of physical parameters also follows the setup used for the WRF or WRF-Chem model over Poland (Bilińska et al., 2017; Kryza et al., 2020; Werner et al., 2018).

The meteorological data for the HYSPLIT model were taken from a full-year WRF run and covered the dates of dispersion model simulation (27.03.2015 to 14.05.2015 and from 01.04.2016 to 11.05.2016). The full list of parameters from WRF used by the HYSPLIT is included in Appendix as a Table 4 (source: NOAA webpage); the main parameters include wind components, precipitation, temperature, pressure, and boundary layer height.

\subsection{Description of the emission model}

The birch emission model was based on the parametrization in Sofiev et al. (2013), which in turn is based on the double-threshold temperature sum. The temperature sum is calculated from the 1st of March, while the threshold temperature is kept at $3.5^{\circ} \mathrm{C}$. Besides the temperature, the emission model is also sensitive to the precipitation rate, relative humidity and wind speed. High humidity $(>80 \%)$ and precipitation $\left(>0.5 \mathrm{~mm} \mathrm{hr}^{-1}\right)$ stifle the release of pollen, whereas an increased wind speed favours it (Sofiev et al., 2013). The potential emission (the amount of pollen that can be released from trees unlimited by any factor) was calculated for the whole of Europe based on the ERA5 reanalysis dataset (https://www.ecmwf. int/) and available at ca. $30 \times 30 \mathrm{~km}$ grid. The following parameters were extracted from ERA5: temperature at $2 \mathrm{~m}$, relative humidity, wind components and precipitation. To calculate the grid cell emission, 


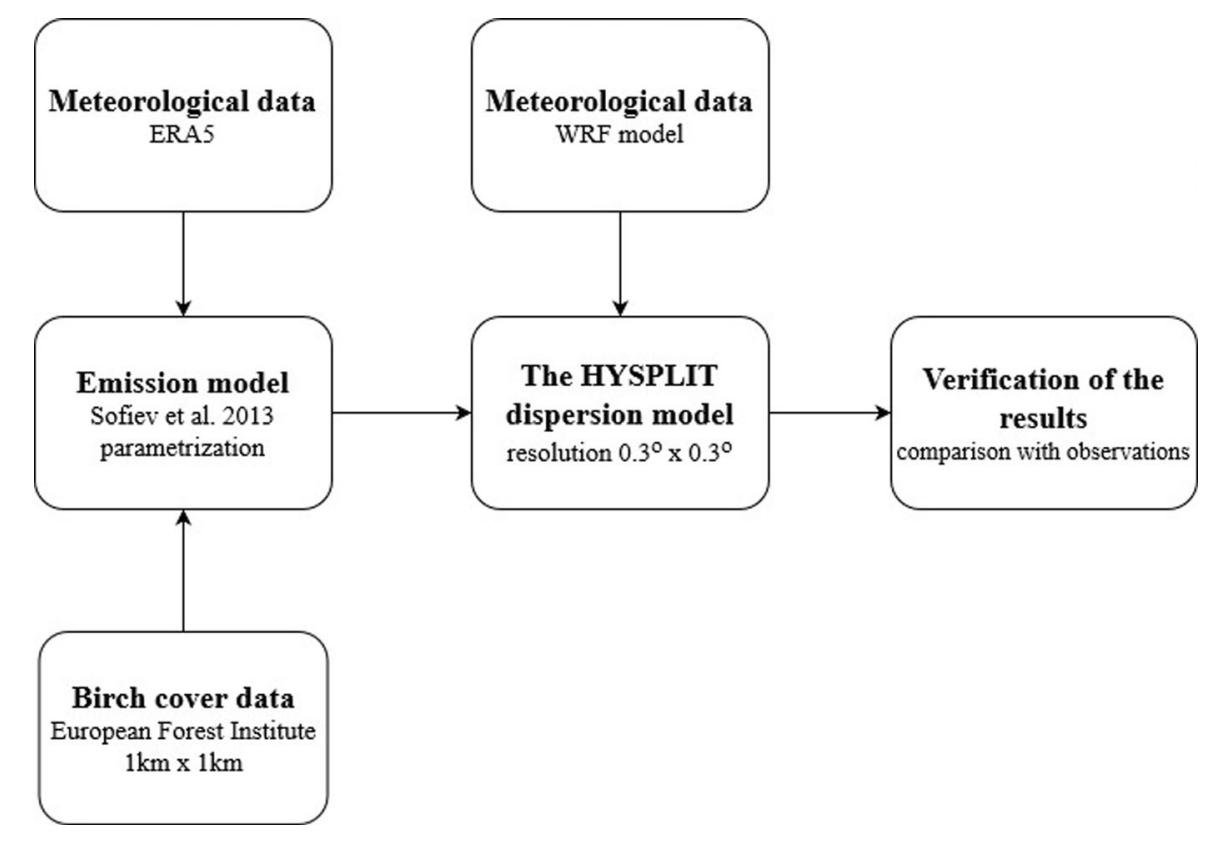

Fig. 1 Flowchart of the birch pollen modelling process

the potential emission was multiplied by the data on birch coverage from the European Forest Institute, which is characterised by a high spatial resolution of $1 \times 1 \mathrm{~km}$ (Brus et al., 2012). Due to computational time reduction of the HYSPLIT dispersion model, the results obtained were transformed to grids with $0.3^{\circ} \times 0.3^{\circ}$ spatial resolution. Calculations were carried out using the $\mathrm{R}$ statistical software (R-Core Team, 2019).

\subsection{HYSPLIT dispersion model settings}

The HYSPLIT model simulations, with one-hour temporal resolution, were run from 27 March 2015 to 14 May 2015 and from 1 April 2016 to 11 May 2016. These dates covered the main pollen season. (The start of the main pollen season was set as the earliest start from all stations, whereas the end of the main pollen season was set as the latest end from all stations.) The emission introduced to the model was set as point sources, which covered Central Europe at a resolution of $0.3^{\circ} \times 0.3^{\circ}$ (Fig. 2). The scavenging coefficient was set at $3 \times 10^{-3}$ both for in and below cloud (Yamartino, 1985). Gravitational settling velocity was set at $1.2 \mathrm{~cm} \mathrm{~s}^{-1}$ as in Sofiev et al. (2006). The diameter of pollen was set at $22 \mu \mathrm{m}$ (Biedermann et al., 2019), whereas density was set at $800 \mathrm{~kg} \mathrm{~m}^{-3}$
(Zhang et al., 2014). The in-line conversion model used in the HYSPLIT model was set to deposit particles rather than reduce their mass (Draxler et al., 2020).

The results presented in chapters $3 \mathrm{a}-3 \mathrm{~d}$ are based on simulations with the basic version of the emission model described in the section above (BASE run). These emissions do not use a scaling factor dependent on the seasonal pollen integral (SPIn), which has been suggested by, among others, Kurganskiy et al. (2020). Our further application of the model will concern daily pollen forecasts, for which the calculation of such a factor is not possible. However, to show the importance of the inclusion pollen data in the source map creation, we have calculated the SPIn factor for all stations by dividing SPIn from observation by SPIn from the model run and interpolating it for the whole Poland and then multiplied the basic emissions by this factor. The results of the HYSPLIT model with the scaled emission (SF run) are presented in Sect. 3.5.

\subsection{HYSPLIT backward trajectories}

We calculated 72-h backward trajectories to check whether 2016 birch pollen concentrations in Wrocław were under the influence of long-distance transport. The backward trajectories were calculated every $2 \mathrm{~h}$ 


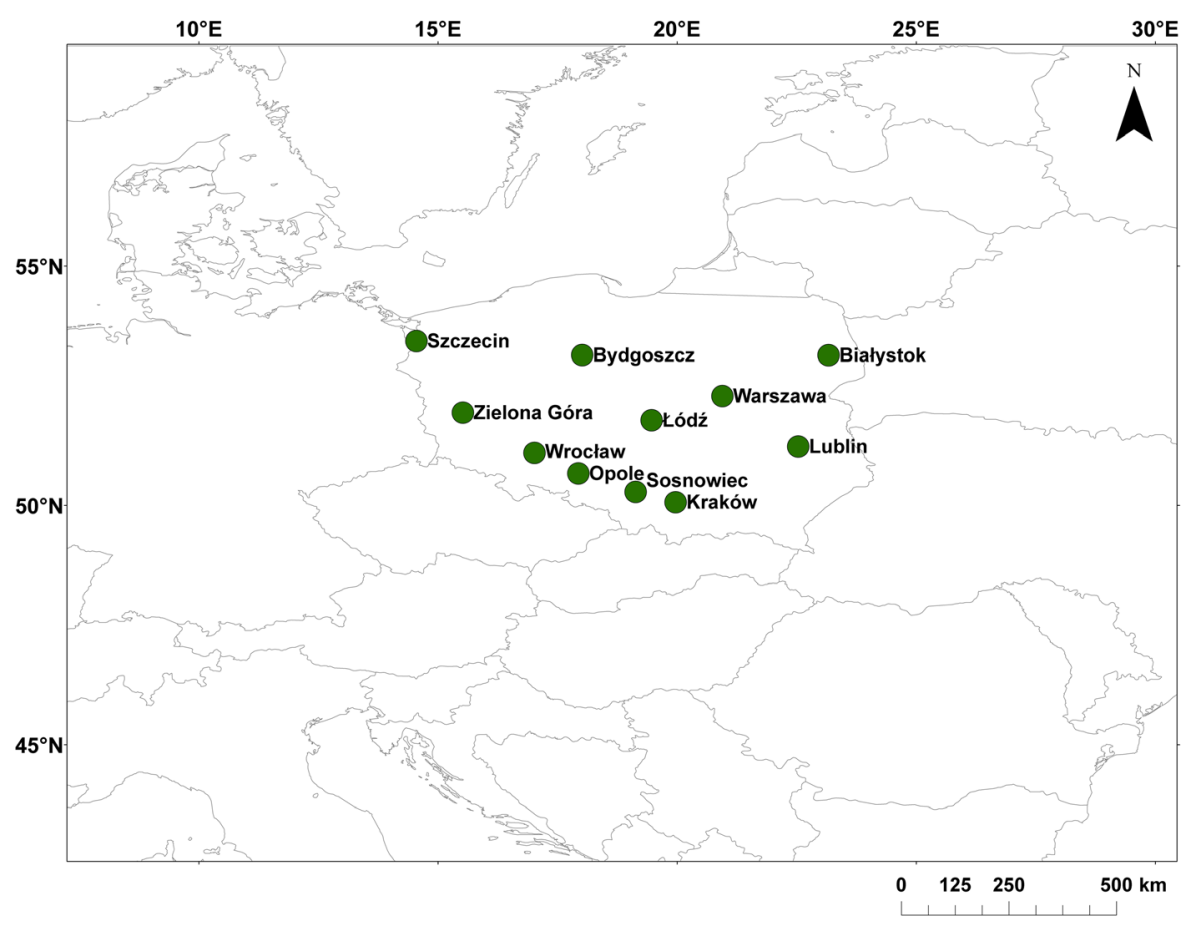

Fig. 2 The HYSPLIT model domain and location of the birch pollen sampling sites

ending the day before and on the day of the highest peak of birch pollen, which was also the starting day of the pollen season in Wrocław. The receptor point was at $2000 \mathrm{~m}$ a.g.l. as used by Grewling et al. (2019) for long-range transport analysis.

\subsection{Model evaluation}

The modelled birch pollen concentrations were aggregated to the daily mean values and compared with observations. For the modelled data using the $95 \%$ method, we determined the start and end of the pollen season, length of the pollen season and SPIn. We then compared them with those obtained from observational data. We calculated the normalized mean bias (NMB), normalized mean absolute error (NMAE), Pearson correlation coefficient (R), fractional bias (FB) and fractional absolute error (FAE) (Table 1) (Emery et al., 2017) for the whole pollen season. The statistics were calculated for the main pollen season in Poland (i.e. 11 April-12 May 2015 and 4 April-9 May 2016) as suggested by Sofiev et al. (2015); Kurganskiy et al. (2020). Calculations were carried out in the $\mathrm{R}$ language (R-Core Team, 2019) using the package 'openair'.

\section{Results}

3.1 Start and end of the pollen season and SPIn value for the BASE run

The 2015 birch pollen season, calculated with the BASE run, started earlier when compared with observations. The difference between the observed and modelled data reached on average 9 days (Fig. 3). In the case of the season's end, the difference was on average 8 days and the model simulates the end of the season somewhat earlier. In 2015, the length of the pollen season for observational data lasted from 18 days in Wrocław and Warszawa to 30 days in Łódź, whereas for the BASE run it lasted from 16 days in Bydgoszcz to 29 days in Zielona Góra. In general, the length of the season according to the model was longer compared to observations at 7 of the 11 stations. According to the observed data, the birch pollen season in 2016 started earlier than in 2015, and in most cities it was 5-6 April 2016. The model simulates the start on average 2 days earlier compared to observations. As to the season's end, the model also performed an earlier end (on average 13 days earlier than observations). The range of the season's length 
Table 1 The statistical metrics used to quantify the HYSPLIT model performance( $M$ modelled value, $O$ observed value, $n$ number of values

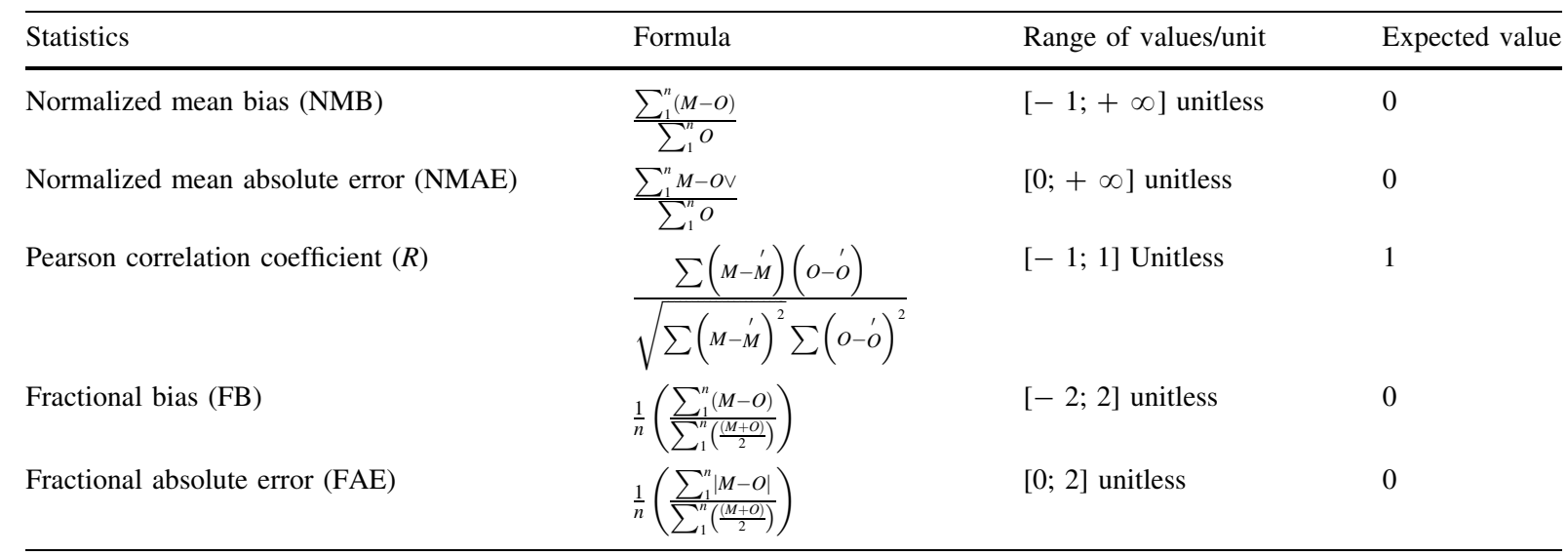

for observational data was from 27 to 34 days, whereas for the modelled data it was from 15 to 29 days. The closest agreement between the length of the season for the model (30 days) and observations (29 days) was for Bydgoszcz (central Poland).

In 2015, the SPIn was similar for both modelled and observed data and did not exceed 6000 pollen $\mathrm{m}^{-3}$ (Fig. 4). In the case of SPIn, for Łódź and Wrocław (SW and central Poland) the difference in the SPIn between observed and modelled values reached -157 (modelled value was $105 \%$ of observed value) and 784 pollen $\mathrm{m}^{-3}(82 \%)$, respectively, whereas for Białystok (NE Poland), it was -3918 pollen $\mathrm{m}^{-3}$ (499\%). In 2016, the seasonal pollen integral (SPIn) for the observation data was very high, reaching a range of 8470 pollen $\mathrm{m}^{-3}$ in Szczecin to 36,510 pollen $\mathrm{m}^{-3}$ in Lublin. For the BASE run data, the SPIn value was lower compared to the observational one, which reached a maximum of 7383 pollen $\mathrm{m}^{-3}$ for Białystok.

\subsection{Pollen concentrations for the BASE run}

The time series of modelled and observed birch pollen concentrations are presented in Fig. 5. For 2015, the model reproduced the main observed peaks; however, in some cities a shift between the observed and modelled peak can be observed (e.g. for Bydgoszcz or Łódź). The modelled concentrations of birch pollen were higher when compared to the measurements. The start and end of the seasons were earlier for the BASE run compared to the observed values.
In 2016, the model (BASE run) was able to reproduce the timing of the peaks, but it was not able to perform the peak of pollen concentration, which occurred at the end of the season. Observed concentrations were underestimated by the model at all stations, which was also confirmed by statistical measures (Fig. 6).

\subsection{Model performance for the BASE run}

In 2015, the model overestimated the observed birch pollen concentrations at most of the stations-normalised mean bias (NMB) was positive at 8 of 11 stations. NMB ranged from -0.44 for Opole to 2.53 for Białystok (Fig. 6). Normalized mean absolute error (NMAE) in 2015 ranged from 0.52 for Opole to 3.62 for Białystok. The second nearest to the expected NMAE value was observed for Bydgoszcz at 1.56. At 4 stations, the correlation coefficients $(R)$ were equal to or above 0.5 ( $p$-value $<0.05)$. Białystok was the only site with negative $R(-0.04)$. Fractional bias (FB) for all stations was below zero, ranging from -0.18 for Warszawa to -0.83 for Opole. The fractional absolute error (FAE) for 9 stations was above 1 , and in all stations ranged from 0.89 for Kraków to 1.49 in Białystok. The lowest FAE values were visible for the south-western part of Poland; this region was also characterised by the highest correlation coefficient and the nearest to expected NMAE values.

For 2016, the model underestimated the pollen concentrations-NMB was negative for all stations. 


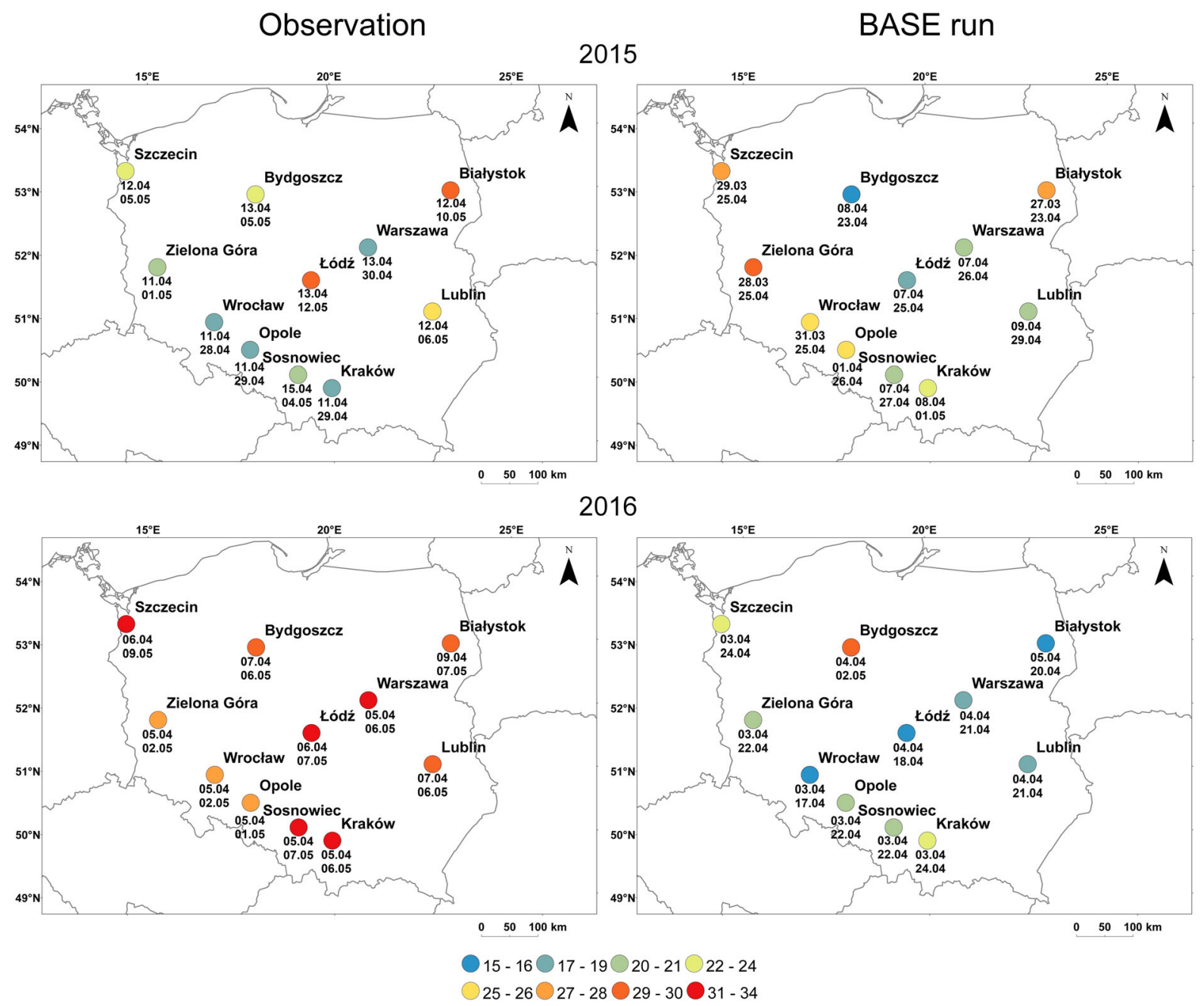

Fig. 3 The length of the season for observational (left) and BASE run (right) data in 2015 and 2016 shown by colour dots. Dates of the start and end of the pollen season are given below the dots

NMAE ranged from 0.83 (Zielona Góra) to 1.25 (Białystok). In only 1 of 11 stations was the $\mathrm{R}$ coefficient equal to or above 0.5 (with $p$-value $<$ 0.01). At one station (Białystok), the correlation coefficient was negative. In the case of $\mathrm{FB}$, its value was below zero for all cities. The range was from -0.97 (Białystok) to -1.63 (Lublin). At all cities, the FAE was higher than 1.4. The lowest value of this measure was for Zielona Góra (1.42) and the highest was for Lublin (1.82). The mean correlation coefficient, calculated for all stations, is equal to 0.44 for 2015 ( $p$-value $<0.001)$ and 0.22 for 2016 ( $p$ value $<0.001)$.

\subsection{HYSPLIT backward trajectory analysis}

Underestimation of birch pollen concentrations for the year 2016 was analysed in terms of long-term transport. Backward trajectories were calculated for Wroclaw, which was one of the stations with the highest underestimation of measured concentrations. The trajectories were presented at the map with birch cover over Europe to determine whether air masses passed over areas with high birch-tree coverage (Fig. 7). These areas could be potential sources of birch pollen transported to Poland. A similar approach has been previously presented by Skjøth et al. (2015) for alder, birch and oak as well as by Bogawski et al. (2019) and Skjøth et al., (2007, 2009) for birch. 

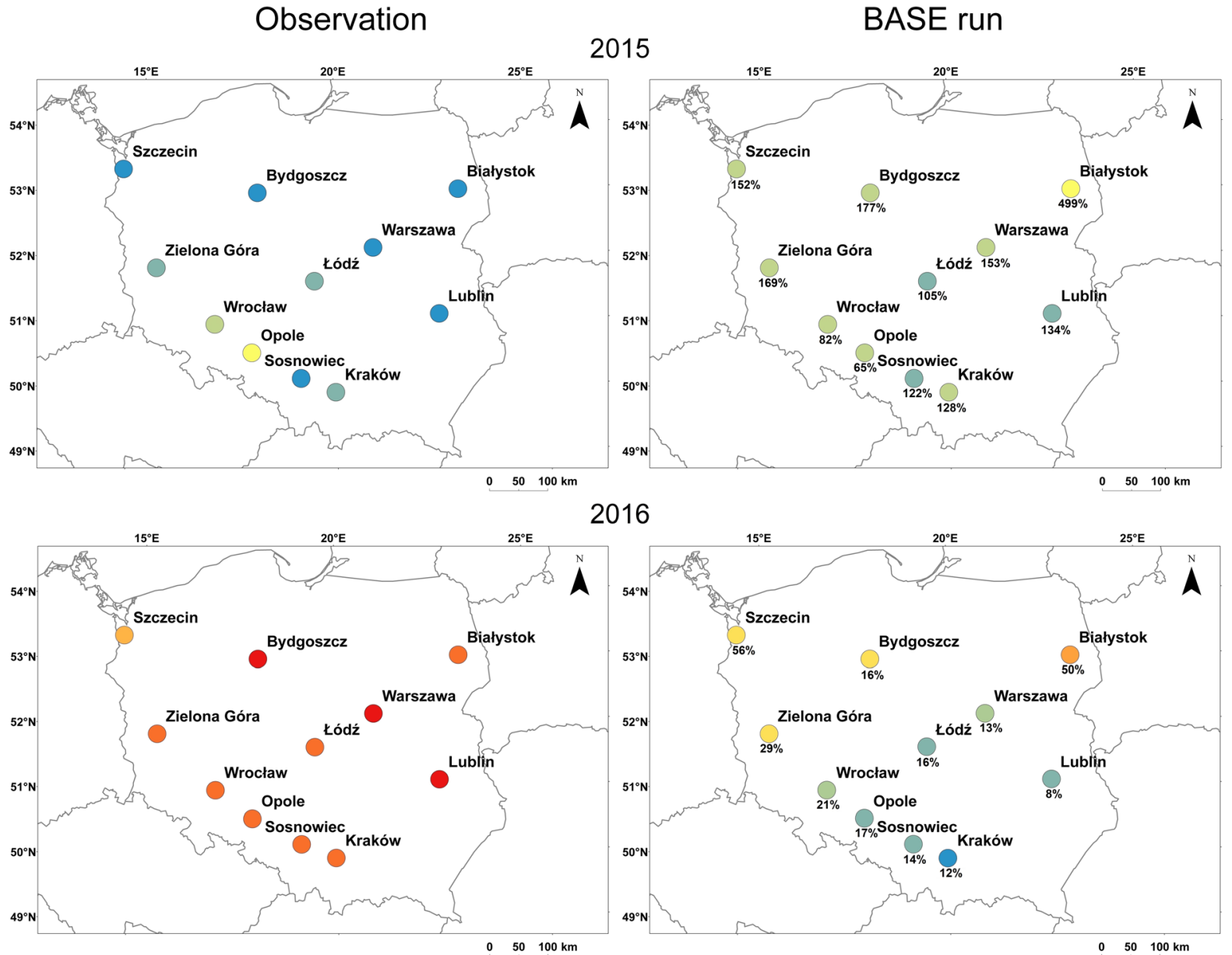

$981-2429 \bigcirc 2430-3103 \bigcirc 3104-4521 \bigcirc 4522-5987$

5988 - $8470 \bigcirc 8471$ - $20380 \bigcirc 20381$ - 36510

Fig. 4 The seasonal pollen integral calculated using the observed (left) and BASE run data (right) for the 2015 and 2016 birch pollen seasons. Percentage SPIn error counted as

Analysis of backward trajectories showed that during the highest peak in Wrocław in 2016, air masses came from south-eastern and southern Europe (Fig. 7). On 3 April 2016, flows of air masses were observed from the south-western part of Europe, eastern France and south-eastern Germany, whereas on the next day the flow of air masses changed to a southern direction and crossed northern Italy, Slovakia, and northern parts of the Czech Republic. During both days, air masses crossed regions with high birch coverage like northern Italy, south-eastern Germany and northern parts of the Czech Republic.
SPIn from the model divided by the SPIn from observation and multiplied by 100 (percentage values below dots)

Fig. 5 The results of the modelled (BASE run and SF run) and observed pollen concentrations at all stations in 2015 (left) and 2016 (right)

\subsection{SF run results compared to the BASE run}

The time series of birch pollen concentrations for the SF run are presented in Fig. 5. The model was able to reproduce the main peaks, but a shift between the SF run and observations was observed (e.g. for Białystok in 2016 or Łódź in 2015). For 2015, the modelled concentrations of birch pollen, for the SF run, were overestimated compared to the observations. For 
2015

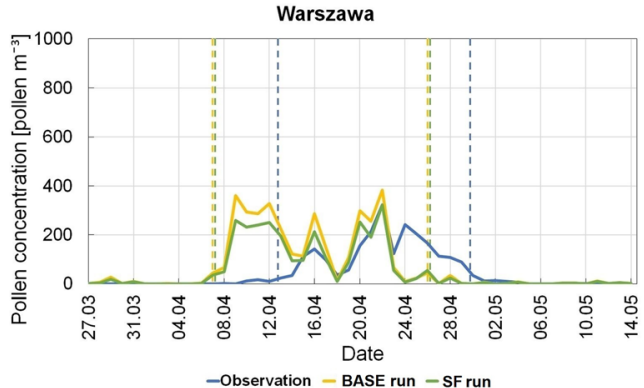

Białystok

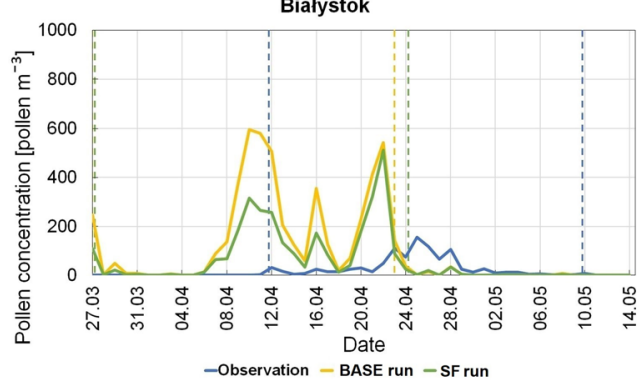

Bydgoszcz

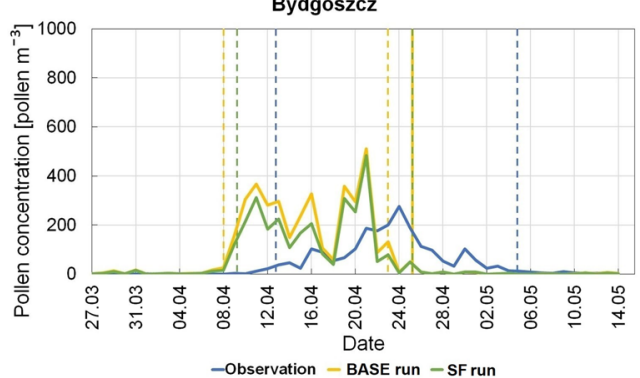

Kraków

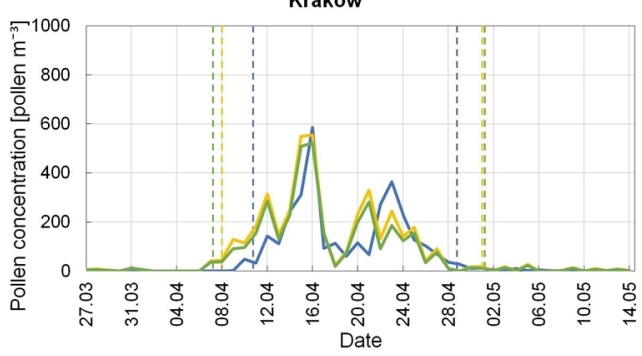

-Observation - BASE run - SF run

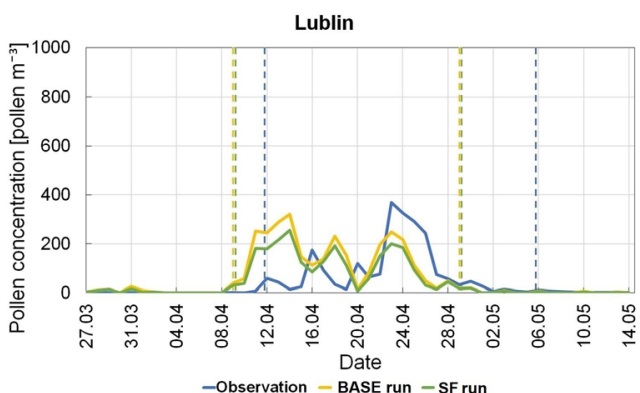

2016

Warszawa

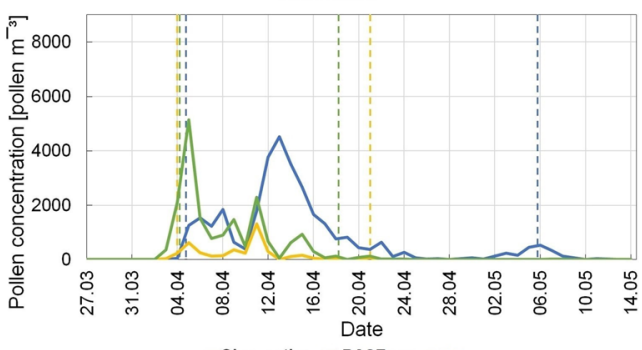

-Observation - BASE run - SF run

Białystok

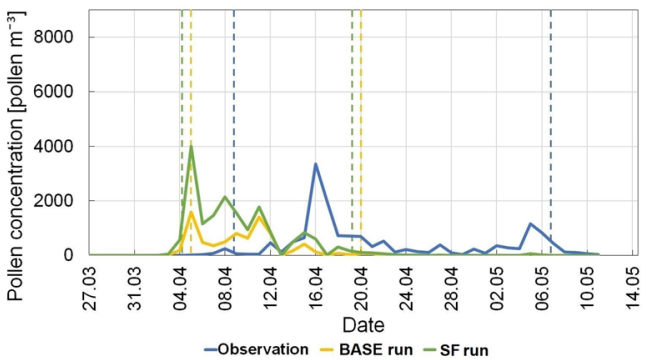

Bydgoszcz

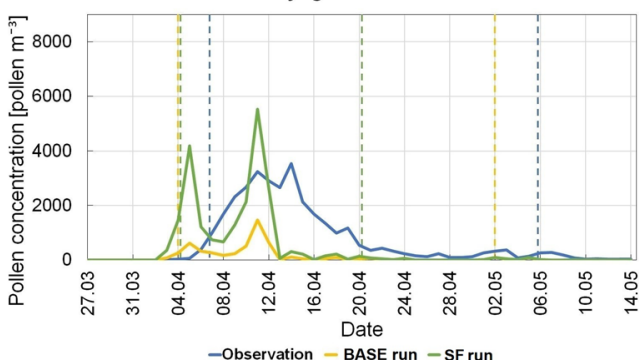

Kraków

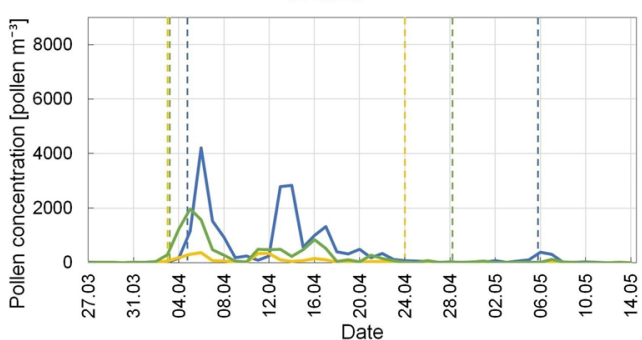

-Observation - BASE run - SF run

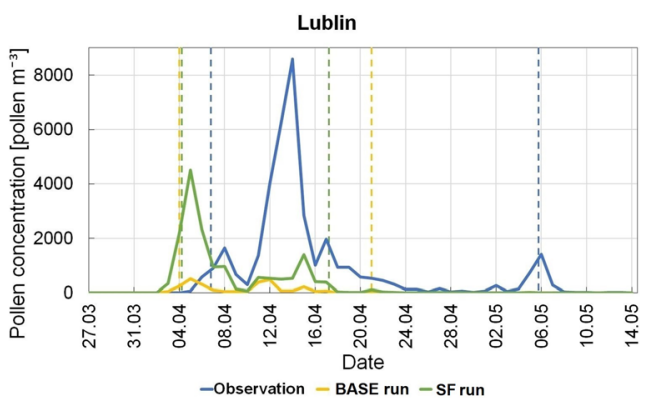


Fig. 5 continued
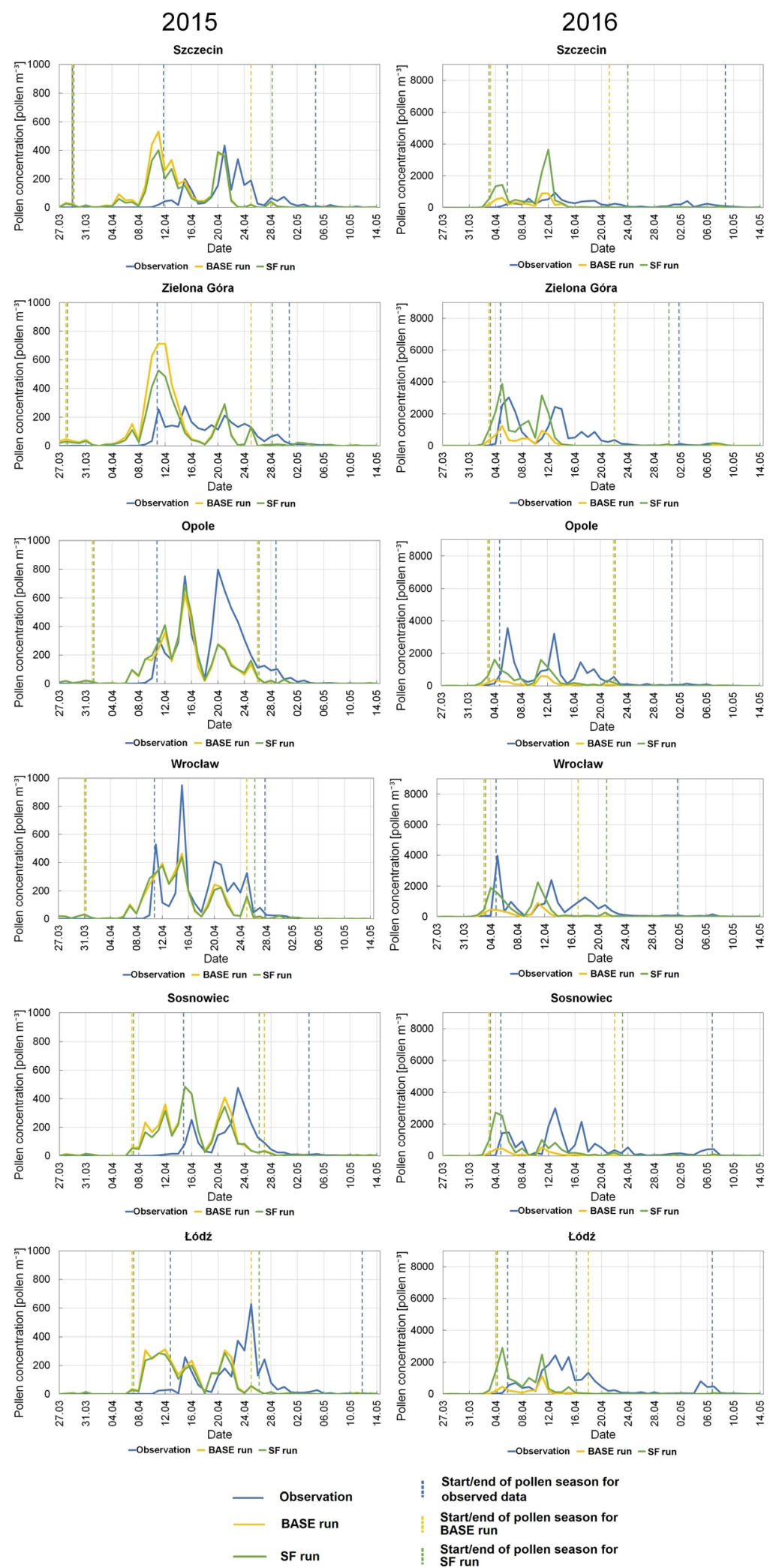

$$
\begin{aligned}
& \text { Start/end of pollen season for } \\
& \text { observed data } \\
& \text { Start/end of pollen season for } \\
& \text { BASE run } \\
& \text { Start/end of pollen season for } \\
& \text { SF run }
\end{aligned}
$$


Table 2 A comparison of statistics for the BASE and SF run for 2015

\begin{tabular}{|c|c|c|c|c|c|c|c|c|c|c|c|c|}
\hline & \multirow{2}{*}{$\begin{array}{l}\text { BASE } \\
\text { NMB }\end{array}$} & \multirow[t]{2}{*}{ SF } & \multirow{2}{*}{$\begin{array}{l}\text { BASE } \\
\text { NMAE }\end{array}$} & \multirow[t]{2}{*}{ SF } & \multicolumn{2}{|l|}{ BASE } & \multicolumn{2}{|l|}{ SF } & \multirow{2}{*}{$\begin{array}{l}\text { BASE } \\
\text { FB }\end{array}$} & \multirow[t]{2}{*}{ SF } & \multirow{2}{*}{$\begin{array}{l}\text { BASE } \\
\text { FAE }\end{array}$} & \multirow[t]{2}{*}{ SF } \\
\hline & & & & & $\mathrm{R}$ & p-value & $\mathrm{R}$ & $\mathrm{p}$-value & & & & \\
\hline Warszawa & 0.19 & -0.04 & 1.00 & 0.82 & 0.44 & 0.01 & 0.44 & 0.01 & -0.18 & -0.28 & 1.15 & 1.13 \\
\hline Białystok & 2.53 & 1.31 & 3.62 & 2.48 & -0.04 & 0.83 & 0.01 & 0.97 & -0.26 & -0.37 & 1.49 & 1.43 \\
\hline Bydgoszcz & 0.54 & 0.20 & 1.56 & 1.33 & 0.19 & 0.29 & 0.21 & 0.26 & -0.54 & -0.71 & 1.36 & 1.44 \\
\hline Kraków & 0.19 & 0.05 & 0.57 & 0.54 & 0.81 & 0.00 & 0.81 & 0.00 & 0.10 & 0.01 & 0.89 & 0.87 \\
\hline Lublin & 0.31 & 0.03 & 1.14 & 1.01 & 0.33 & 0.07 & 0.35 & 0.05 & -0.29 & -0.42 & 1.14 & 1.18 \\
\hline Szczecin & 0.13 & -0.02 & 1.10 & 1.01 & 0.32 & 0.07 & 0.38 & 0.03 & -0.67 & -0.67 & 1.31 & 1.27 \\
\hline Zielona Góra & 0.17 & -0.06 & 1.02 & 0.83 & 0.58 & 0.00 & 0.61 & 0.00 & -0.49 & -0.55 & 1.18 & 1.18 \\
\hline Opole & -0.44 & -0.38 & 0.52 & 0.50 & 0.77 & 0.00 & 0.74 & 0.00 & -0.83 & -0.81 & 1.05 & 1.00 \\
\hline Wrocław & -0.32 & -0.35 & 0.59 & 0.60 & 0.77 & 0.00 & 0.77 & 0.00 & -0.49 & -0.51 & 0.95 & 0.97 \\
\hline Sosnowiec & 0.39 & 0.26 & 1.29 & 1.19 & 0.31 & 0.08 & 0.31 & 0.08 & -0.28 & -0.40 & 1.18 & 1.24 \\
\hline Łódź & -0.15 & -0.22 & 1.10 & 1.04 & 0.10 & 0.59 & 0.10 & 0.57 & -0.53 & -0.56 & 1.40 & 1.37 \\
\hline MEAN & 0.32 & 0.07 & 1.23 & 1.03 & 0.42 & & 0.43 & & -0.40 & -0.48 & 1.19 & 1.19 \\
\hline
\end{tabular}

2016, they were underestimated. The start and end of the seasons were earlier for the SF run compared to the observed values. The start of the pollen season was almost the same as for the BASE run. There were differences in case of the end of the pollen season for the BASE run and SF run-for some cities, the season ended later for the SF run compared to the BASE run (e.g. for Kraków or Zielona Góra in 2016), but for others the SF run ended earlier compared to the BASE (Warszawa and Bydgoszcz in 2016). These differences were more noticeable in 2016.

In 2015 for the SF run, the NMB ranged from - 0.38 (Opole) to 1.31 (Białystok) (Table 2). For six out of 11 stations, the model underestimates the pollen concentration. The $\mathrm{R}$ correlation coefficient was positive for all stations and ranged from 0.01 for Białystok to 0.77 for Wrocław. The SF run was characterized by a lower NMB compared to the BASE run. The SF run also made it possible to reduce NMAE. The value of FAE does not change, which was 1.19 in both runs (Table 2).

In 2016, the SF simulation was underestimated for nine out of 11 stations. For 10 out of 11 stations, the $\mathrm{R}$ coefficient ranged from 0.06 (Lublin) to 0.44 (Bydgoszcz); for one station it was negative. The FB was negative for all stations and ranged from -1.32 (Lublin) to -0.61 (Kraków). For all stations, the FAE was above 1, ranging from 1.06 (Kraków) to 1.65 (Białystok). The SF run made it possible to reduce the NMB value from -0.78 to -0.29 , compared to the BASE run. The value of FB was also improved-from
-1.43 for the BASE run to -1.01 for the SF run. The SF run was characterized by a higher NMAE value (1.05) compared to the BASE run (0.93) (Table 3).

\section{Discussion}

The use of dispersion models allows us to estimate the pollen concentration in places where no pollen station exists or where the number of stations is insufficient. The models can also be used for short-term forecasts to alert those allergic as to the start of the season or high pollen concentrations (Hoebeke et al., 2019). In this study, we used the HYSPLIT dispersion model to calculate birch pollen concentrations over Poland for two years that varied according to characteristics of the birch pollen season. We chose the year 2015 for which the SPIn value was low and 2016 for which the SPIn was several times higher. We performed two HYSPLIT model runs. In the first run (BASE), we did not apply any coefficient for the emission data. In the second run (SF), we used the SPIn scaling factor for these data. The model for the BASE run tended to overestimate the observed concentrations (NMB above 0 for eight stations out of eleven) for the year 2015. For some stations, the NMB reached values close to 0, i.e. 0.13 for Szczecin, -0.15 for Łódź and 0.17 for Zielona Góra. In 2016, for the BASE run, there was a major underestimation of pollen concentrations at all stations. This was confirmed by the $\mathrm{NMB}$, which was equal to or below -0.5 at 10 of the 
Table 3 A Comparison of statistics for the BASE and SF run for 2016

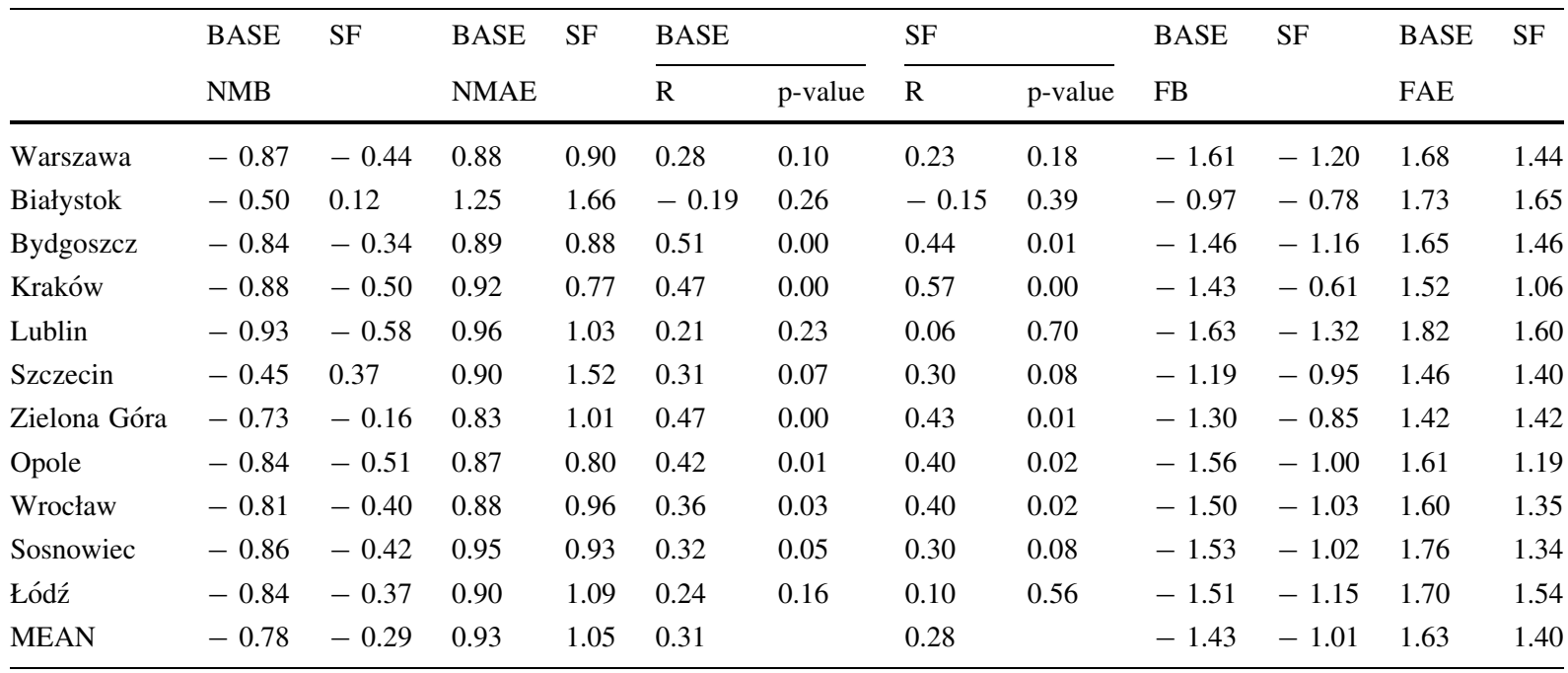

11 stations. The modelled SPIn for 2015 reflected SPIn from observations, whereas for 2016 its value was underestimated. The correlation coefficient between modelled and observed birch pollen concentrations ranged from -0.04 to 0.81 in 2015 and from -0.19 to 0.51 in 2016 . The statistical measures were similar to research conducted by Verstraeten et al. (2019) who used the SILAM model to calculate birch pollen levels in Belgium. The correlation coefficient obtained for their simulation ranged from 0.29 to 0.59 (Verstraeten et al., 2019). Our study also showed that the fractional bias (FB) and fractional absolute error (FAE) were better in 2015 compared to 2016. In 2015, FB did not exceed -0.18 and FAE was no closer to the expected value than 1.49 (Fig. 6). In 2016, the FB value nearest to the expected value was -0.97 , while for the FAE value it was 1.42 .

Although statistical measures showed better model performance in 2015 than in 2016, the model for the BASE run and was not able to correctly calculate the start and end of the season for the year 2015. For 2015, the modelled season started on average 9 days earlier and ended on average 8 days earlier compared to observational values. In 2016, the model was able to simulate the start of the pollen season correctly (2-day difference compared to observation), whereas the end of the season was simulated on average 13 days too early compared to observation. The start of the season is very sensitive on temperature. In 2016, the start of the season was connected with a long-distance transport (Myszkowska et al., 2021); thus, potential bias of
Fig. 6 The HYSPLIT model error statistics for the BASE run, for the year 2015 (left) and 2016 (right). The P-value for R is given below the dots

temperature for Poland is not as significant as in 2015, for which the start of the season was related to flowering from local trees. Variability was also noticeable with respect to the length of the season. For 2015, from observations the season was calculated to last from 18 to 30 days, whereas in 2016 it was from 27 to 34 days (Fig. 3). The difference was also observed at the beginning of the season. In 2015, it started later (between April 11 and April 15) than in 2016, where the onset of the pollen season was between April 5 and April 9.

Based on the spatial distribution of stations, it could be noted that especially in 2015 the model performance for the BASE run was better for western and south-western Poland (Zielona Góra, Wrocław, Opole). For north-eastern Poland (Białystok), the model results were worse. These differences were most pronounced in terms of the NMAE. Białystok is located in an area with the greatest continental influence in Poland, which is visible particularly in cases of long and cold winters (Kossowska-Cezak, 2007). In this region, the frequency of days with moderately warm, sunny weather without precipitation is relatively low compared with the rest of Poland (Woś, 1993). It was difficult to indicate the region characterised by better results for the year 2016 . 
2015

(a)

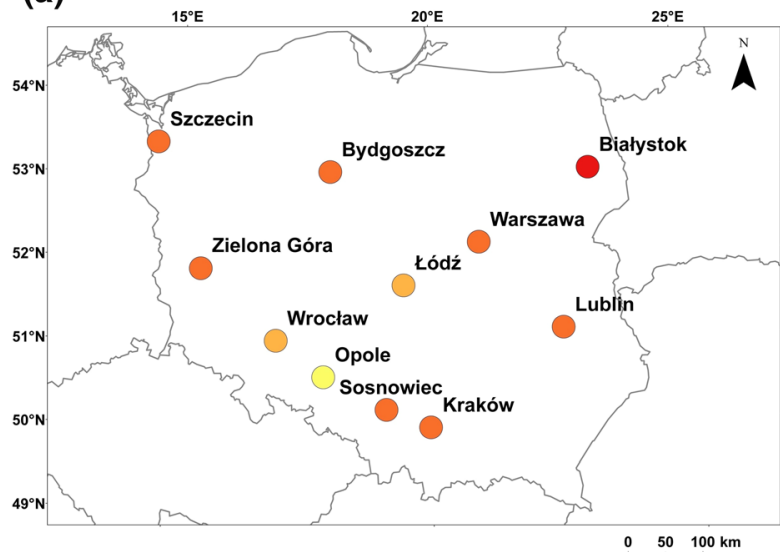

2016

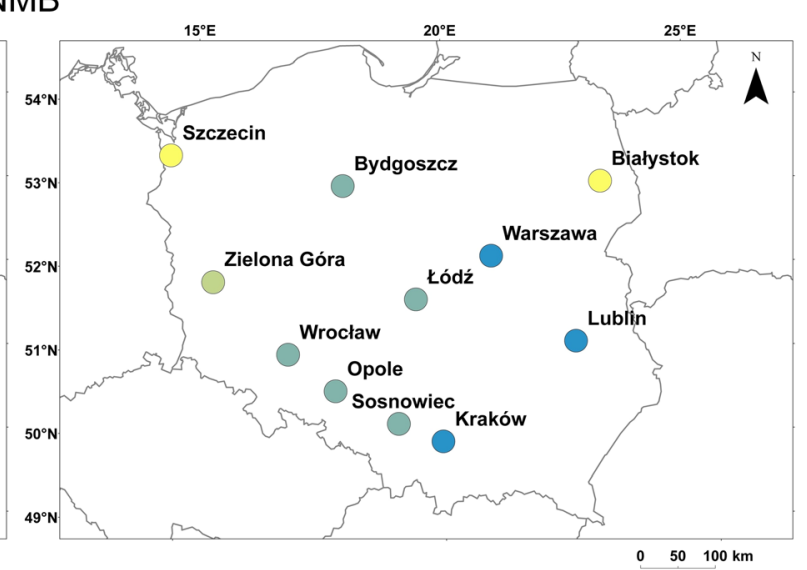

$-0,93--0,87 \bigcirc-0,86--0,81 \bigcirc-0,80--0,73 \bigcirc-0,72--0,44$

- $0,43--0,15 \bigcirc-0,14-0,54 \bigcirc 0,55-2,53$

(b)

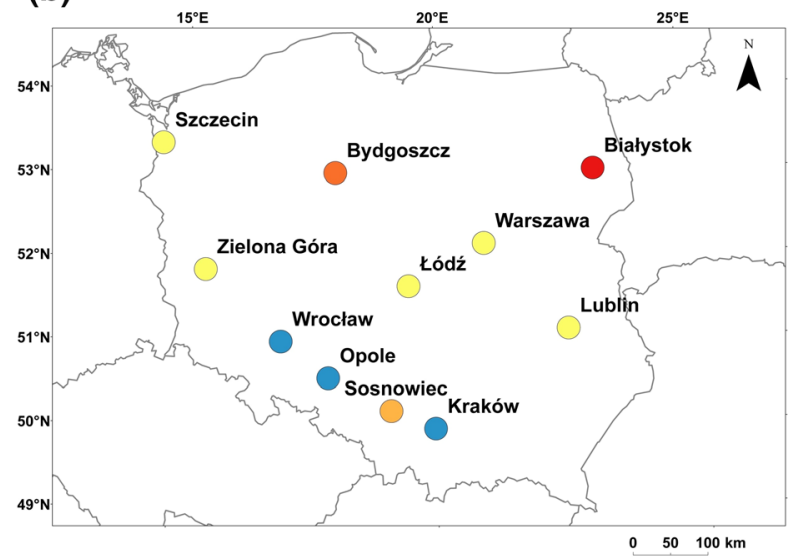

NMAE

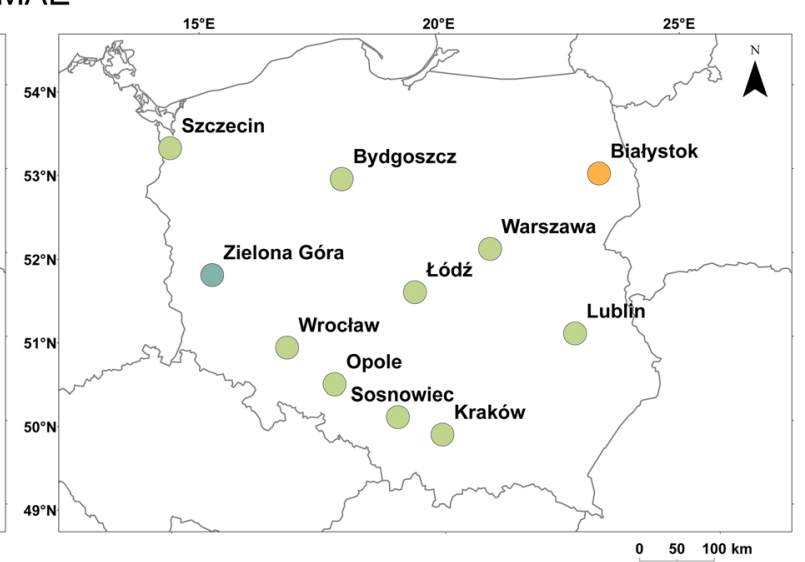

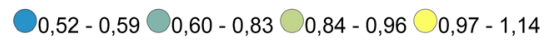

1,15 - 1,29 1,30 - 1,56 1,57 - 3,62

(c)

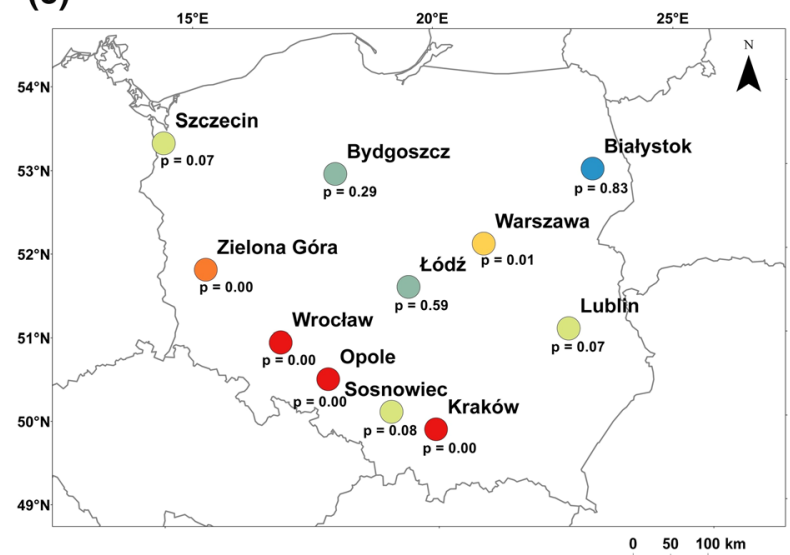

$\mathrm{R}$

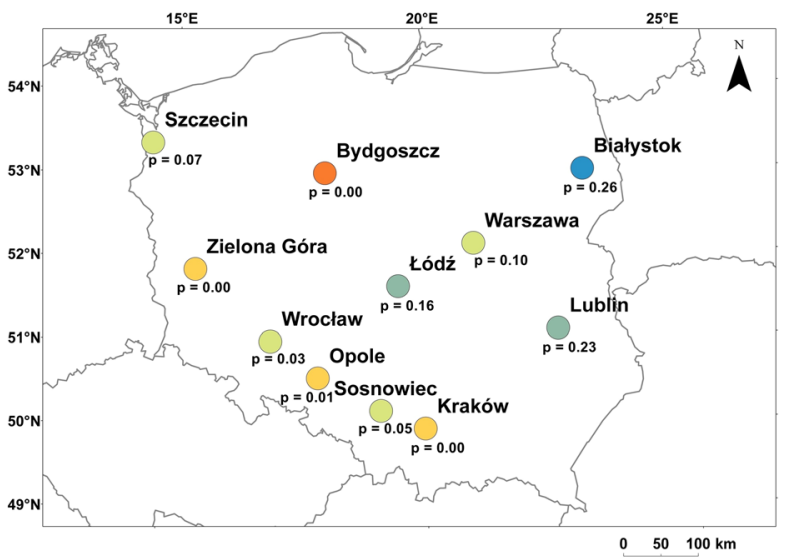

$-0,19--0,04 \bigcirc-0,03-0,24 \bigcirc 0,25-0,36$

$0,37-0,47 \bigcirc 0,48-0,58 \bigcirc 0,59-0,81$ 


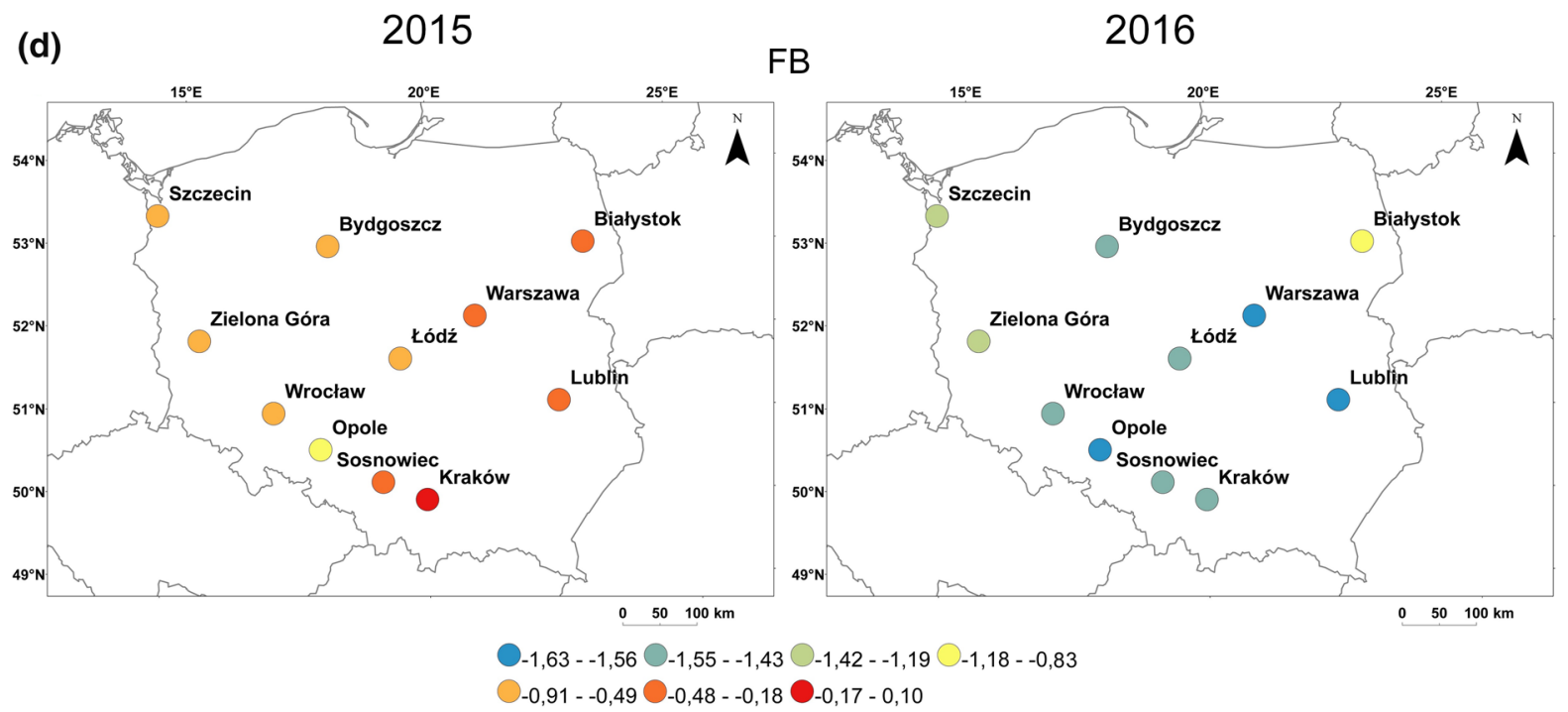

(e)

FAE

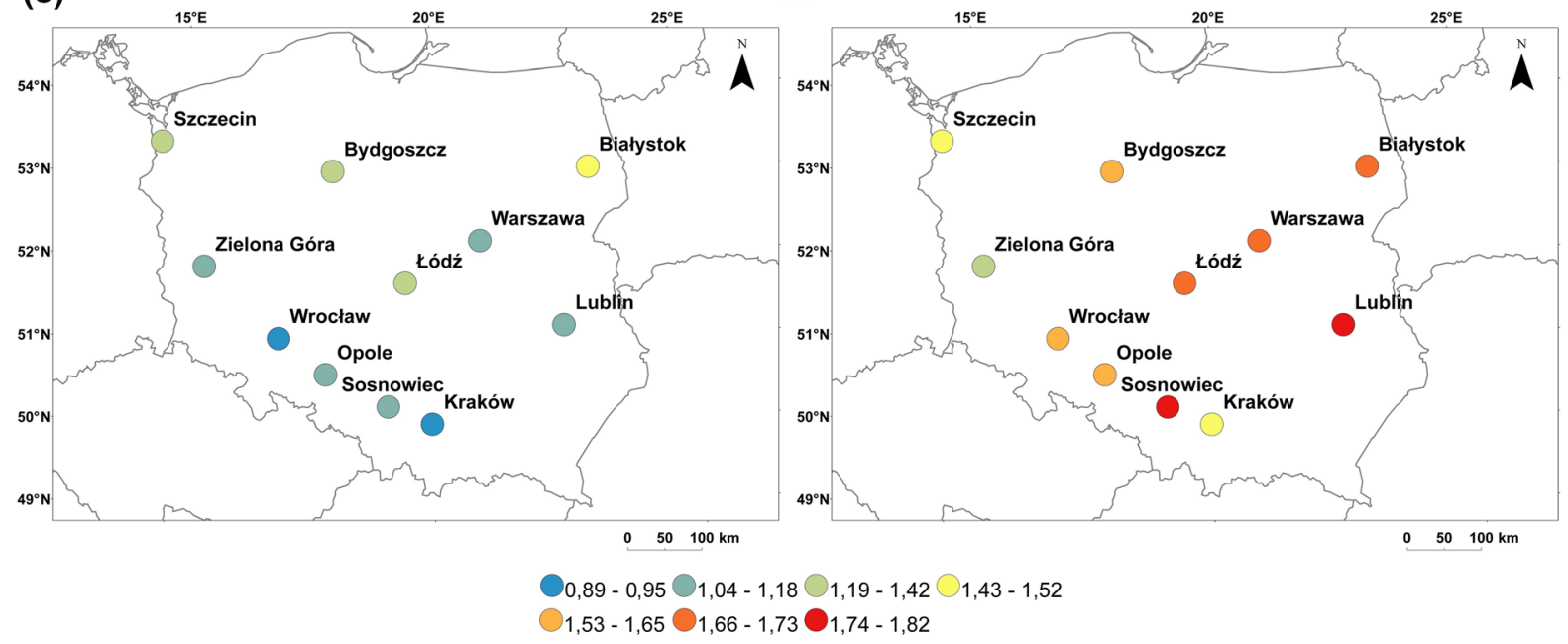

Fig. 6 continued

However, the lowest correlation coefficient was the same as for 2015 for the Bialystok station.

There are a few factors that influence the model results. Accurate spatial distribution of birch and meteorological data are key input data for regional dispersion modelling (Verstraeten et al., 2019). In our simulations, we used the Forest Map of Europe from the European Forest Institute (Brus et al., 2012), with a high spatial resolution $(1 \times 1 \mathrm{~km})$. The highest annual pollen sums were observed for Warszawa and Lublin; these cities have the highest proportional birch coverage in the surrounding forests (Kubik-Komar et al., 2019). Another factor is the annual variability in birch flowering intensity. Usually, the birch pollen production is noticeably enhanced (Corden \& Millington, 1999; Latałowa et al., 2002; Malkiewicz et al., 2016). However, it was also shown that this rhythm can be interrupted by asynchronous years or when the intensity of pollen seasons is similar during consecutive years (Grewling et al., 2012). Sofiev et al. (2015) have emphasised that a lack of emission model can produce year-to-year birch pollen production. This is important especially in years with higher pollen production, as in 2016. In 2016, the observed concentrations in peak days were a few times higher compared to the year before; in Lublin, it was more than 16 times higher (Kubik-Komar et al., 2019). 


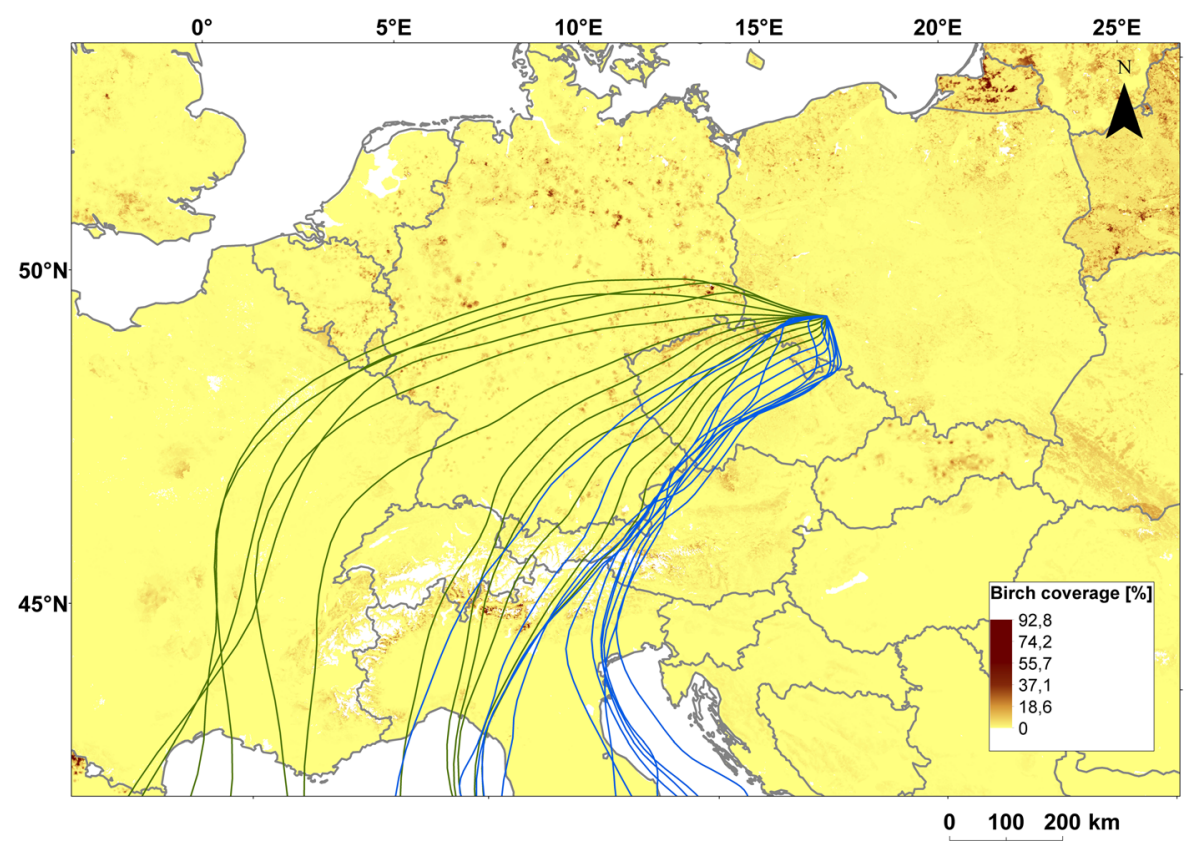

Fig. 7 Backward trajectories for 3 April 2016 (green lines) and 4 April 2016 (blue lines) for Wrocław. Background map showing the presence of birch trees was obtained from the European Forest Institute (https://efi.int/)

The application of the SPIn scaling factor for the emissions improved the model's performance. It is particularly noticeable in the case of NMB — for 2015 global mean NMB was equal to 0.32 for the BASE run, whereas for the SF run it was 0.07. In 2016 it was -0.78 and -0.29 , respectively. The application of the SPIn coefficient does not affect the start date of the pollen season. For 2016, it influenced the end of the season but ambiguously-in some cities the season was longer (Bydgoszcz-12-day difference, Lublin4 days), but shorter in others (e.g. Zielona Góra8 days). In 2015, the SPIn coefficient does not influence the length of the season as much as in 2016 - the biggest difference between the BASE run and SF run was 3 days. These results are different from those obtained by Kurganskiy et al. (2020), where the application of the SPIn factor allowed them to reduce the bias of the end of flowering by 2-3 days at each station.

Additionally, long-distance transport could have affected birch pollen concentrations over Poland in 2016. Our analysis of backward trajectories for Wrocław showed that for the day with the highest birch pollen concentrations, there were air masses transported from southern parts of Europe. The backward trajectories passed through areas with high birch cover and earlier season onset compared to Poland, e.g. northern Italy. Similar suggestions were made by Puc et al. (2016) for Szczecin and Białystok, although these were not confirmed by analysis of trajectories and birch cover map.

\section{Conclusion}

Poland's 2015 and 2016 pollen seasons differed in terms of their onset, seasonal pollen integral (SPIn), and the highest daily pollen concentration. The HYSPLIT model used in this study overestimated the pollen concentrations for 2015 and underestimated those for 2016. The model was able to simulate the start of the pollen season in 2016 (the average shift was 2 days), even though there was a problem with accurately determining the end of the season. For 2015, the model was not able to properly perform both the start and end of the pollen season (on average 9 and 8 days of shift, respectively). Based on the statistics, for 2015 the model performed better for western and south-western Poland, while for the north-eastern part of the country the results were not as accurate. In 2016, the backward trajectories indicated a possible impact of long-range transport on the birch pollen season in Poland. 
The results show that the model can resolve the main peaks of pollen concentrations, which is a step forward in application of the HYSPLIT model for birch pollen forecasting over Poland. The problematic issue is a too early start for the season. We suppose that the application of methods that can reduce the bias of air temperature such as data assimilation or bias correction can improve the calculation of the start of emissions and in consequence the start of the season (Kurganskiy et al., 2020). We also hope to focus on improving the birch cover map with the use of high-resolution, up-todate satellite data, as well as further analysis of its impact on the modelling of concentrations.

Acknowledgements Calculations were carried out using resources provided by the Wrocław Centre for Networking and Supercomputing (https://wcss.pl), Grant No. 170. This work was supported by the Polish National Science Centre No. UMO2017/25/N/ST10/00494 and UMO-2017/25/B/ST10/00926. The authors would like to thank the European Forest Institute for providing the birch distribution map.
Open Access This article is licensed under a Creative Commons Attribution 4.0 International License, which permits use, sharing, adaptation, distribution and reproduction in any medium or format, as long as you give appropriate credit to the original author(s) and the source, provide a link to the Creative Commons licence, and indicate if changes were made. The images or other third party material in this article are included in the article's Creative Commons licence, unless indicated otherwise in a credit line to the material. If material is not included in the article's Creative Commons licence and your intended use is not permitted by statutory regulation or exceeds the permitted use, you will need to obtain permission directly from the copyright holder. To view a copy of this licence, visit http://creativecommons.org/licenses/by/4.0/.

\section{Appendix}

See Appendix Table 4.

Table 4 List of WRF-ARW variables converted to the use of HYSPLIT. (Source: https://www.ready.noaa.gov/data/web/models/ hysplit4/decoders/Note-arw2arl.pdf)

\begin{tabular}{|c|c|c|}
\hline Variable in WRF-ARW & Variable in HYSPLIT & Note \\
\hline$P($ i.e. $P+P B)$ & PRES & Total pressure \\
\hline $\mathrm{T}$ (i.e. $\mathrm{T}+300.0)$ & TEMP & Converting potential temperature(WRF) to ambient temperature \\
\hline U (or AVGFLX_RUM) & UWND & U component of wind (or time-averaged mass coupled u-wind) \\
\hline V (or AVGFLX_RVM) & VWND & V component of wind (or time-averaged mass coupled v-wind) \\
\hline W (or AVGFLX_WWM) & WWND & $\begin{array}{l}\text { Converting vertical velocity }(\mathrm{m} / \mathrm{s}) \text { to omega }(\mathrm{hPa} / \mathrm{s}) \\
\text { (or time-averaged mass coupled eta-dot, unit } \mathrm{Pa} / \mathrm{s} \text {, no conversion) }\end{array}$ \\
\hline $\mathrm{X}$ & DIFW & Writing difference field for greater precision forvertical velocities \\
\hline QVAPOR & SPHU & Water vapor mixing ratio \\
\hline TKE_PBL & TKEN & Turbulent Kinetic Energy (TKE) from PBL schemes \\
\hline $\mathrm{X}$ & DIFT & Writing difference field for greater precision for TKE \\
\hline HGT & SHGT & Terrain elevation \\
\hline PSFC & PRSS & Surface pressure \\
\hline RAIN (i.e.RAINC + RAINNC) & TPP1 & Total precipitation \\
\hline $\mathrm{X}$ & DIFR & Writing difference field for greater precision for precipitation \\
\hline PBLH & PBLH & Boundary layer height \\
\hline UST & USTR & Friction velocity \\
\hline SWDOWN & DSWF & Downward shortwave flux \\
\hline HFX & SHTF & Sensible heat flux \\
\hline LH & LHTF & Latent heat flux \\
\hline $\mathrm{T} 2$ & T02M & Temperatureat $2 \mathrm{~m}$ \\
\hline U10 & U10M & $\mathrm{U}$ component of wind at $10 \mathrm{~m}$ \\
\hline V10 & V10M & $\mathrm{V}$ component of wind at $10 \mathrm{~m}$ \\
\hline
\end{tabular}

' $\mathrm{X}$ ' is not a variable in WRF but a placeholder used in the WRFDATA.CFG to process the difference field for greater precision Source: https://www.ready.noaa.gov/data/web/models/hysplit4/decoders/Note-arw2arl.pdf 


\section{References}

Andersen, T. B. (1991). A model to predict the beginning of the pollen season. Grana, 30(1), 269-275. https://doi.org/10. 1080/00173139109427810

Biedermann, T., Winther, L., Till, S. J., Panzner, P., Knulst, A., \& Valovirta, E. (2019). Birch pollen allergy in Europe. Allergy: European Journal of Allergy and Clinical Immunology, 74(7), 1237-1248. https://doi.org/10.1111/ all.13758

Bilińska, D., Kryza, M., Werner, M., \& Malkiewicz, M. (2019a). The variability of pollen concentrations at two stations in the city of Wrocław in Poland. Aerobiologia. https://doi. org/10.1007/s10453-019-09567-1

Bilińska, D., Kryza, M., Werner, M., \& Malkiewicz, M. (2019b). The variability of pollen concentrations at two stations in the city of Wrocław in Poland. Aerobiologia, 35, 421-439. https://doi.org/10.1007/s10453-019-09567-1

Bilińska, D., Skjøth, C. A., Werner, M., Kryza, M., Malkiewicz, M., Krynicka, J., \& Drzeniecka-Osiadacz, A. (2017). Source regions of ragweed pollen arriving in south-western Poland and the influence of meteorological data on the HYSPLIT model results. Aerobiologia, 33(3), 315-326. https://doi.org/10.1007/s10453-017-9471-9

Bogawski, P., Borycka, K., Grewling, Ł, \& Kasprzyk, I. (2019). Detecting distant sources of airborne pollen for Poland: Integrating back-trajectory and dispersion modelling with a satellite-based phenology. Science of the Total Environment, 689, 109-125. https://doi.org/10.1016/j.scitotenv. 2019.06.348

Brus, D. J., Hengeveld, G. M., Walvoort, D. J. J., Goedhart, P. W., Heidema, A. H., Nabuurs, G. J., \& Gunia, K. (2012). Statistical mapping of tree species over Europe. European Journal of Forest Research, 131(1), 145-157. https://doi. org/10.1007/s10342-011-0513-5

Charalampopoulos, A., Lazarina, M., Tsiripidis, I., \& Vokou, D. (2018). Quantifying the relationship between airborne pollen and vegetation in the urban environment. Aerobiologia, 34(3), 285-300. https://doi.org/10.1007/s10453018-9513-y

Chen, F., \& Dudhia, J. (2001). Coupling an advanced land surface-hydrology model with the Penn State-NCAR MM5 modeling system. Part I: Model implementation and sensitivity. Monthly Weather Review, 129(4), 569-585. https://doi.org/10.1175/1520-0493(2001)129\%3c0569: CAALSH\%3e2.0.CO;2

Clot, B. (2001). Airborne birch pollen in Neuchâtel (Switzerland): Onset, peak and daily patterns. Aerobiologia, 17(1), 25-29. https://doi.org/10.1023/A:1007652220568

Corden, J., \& Millington, W. (1999). A study of Quercus pollen in the Derby area, UK. Aerobiologia, 15(1), 29-37. https:// doi.org/10.1023/A:1007580312019

D'amato, G., \& Spieksma, F. T. M. (1992). European allergenic pollen types. Aerobiologia, 8(3), 447-450. https://doi.org/ 10.1007/BF02272914

Draxler, R., Stunder, B., Rolph, G., Stein, A., \& Taylor, A. (2020). HYSPLIT User's Guide. Air Resources Laboratory NOAA.

Efstathiou, C., Isukapalli, S., \& Georgopoulos, P. (2011). A mechanistic modeling system for estimating large-scale emissions and transport of pollen and co-allergens. Atmospheric Environment, 45(13), 2260-2276. https://doi.org/ 10.1016/j.atmosenv.2010.12.008

Emery, C., Liu, Z., Russell, A. G., Odman, M. T., Yarwood, G., \& Kumar, N. (2017). Recommendations on statistics and benchmarks to assess photochemical model performance. Journal of the Air and Waste Management Association, 67(5), 582-598. https://doi.org/10.1080/10962247.2016. 1265027

Galán, C., Ariatti, A., Bonini, M., Clot, B., Crouzy, B., Dahl, A., Fernandez-González, D., Frenguelli, G., Gehrig, R., Isard, S., \& Levetin, E. (2017). Recommended terminology for aerobiological studies. Aerobiologia, 33(3), 293-295. https://doi.org/10.1007/s10453-017-9496-0

Galán, C., Smith, M., Thibaudon, M., Frenguelli, G., Oteros, J., Gehrig, R., Berger, U., Clot, B., \& Brandao, R. (2014). Pollen monitoring: minimum requirements and reproducibility of analysis. Aerobiologia, 30(4), 385-395. https://doi.org/10.1007/s10453-014-9335-5

Grell, G. A. (2002). A generalized approach to parameterizing convection combining ensemble and data assimilation techniques. Geophysical Research Letters, 29(14), 1693. https://doi.org/10.1029/2002GL015311

Grewling, Ł, Frątczak, A., Kostecki, Ł, Nowak, M., Szymańska, A., \& Bogawski, P. (2019). Biological and chemical air pollutants in an urban area of Central Europe: Co-exposure assessment. Aerosol and Air Quality Research. https://doi. org/10.4209/aaqr.2018.10.0365

Grewling, Ł, Jackowiak, B., Nowak, M., Uruska, A., \& Smith, M. (2012). Variations and trends of birch pollen seasons during 15 years (1996-2010) in relation to weather conditions in Poznań (Western Poland). Grana, 51(4), 280-292. https://doi.org/10.1080/00173134.2012.700727

Hernández-Ceballos, M. A., García-Mozo, H., Adame, J. A., Domínguez-Vilches, E., Bolívar, J. P., De La Morena, B. A., Pérez-Badía, R., \& Galán, C. (2011). Determination of potential sources of Quercus airborne pollen in Cordoba city (southern Spain) using back-trajectory analysis. Aerobiologia, 27(3), 261-276. https://doi.org/10.1007/ s10453-011-9195-1

Hoebeke, L., Se, W. W. V., Bruffaerts, N., Kouznetsov, R., Dendoncker, N., \& Delcloo, A. W. (2019). Spatio-temporal monitoring and modelling of birch pollen levels in Belgium. Aerobiologia, 35(4), 703-717. https://doi.org/10. 1007/s10453-019-09607-w

Janjic, Z. I. (2001). Nonsingular implementation of the MellorYamada level 2.5 scheme in the NCEP meso model. National Centers for Environmental Prediction, National Centers for Environmental Prediction. Office Note 43761.

Jato, V., Rodríguez-Rajo, F. J., Alcázar, P., De Nuntiis, P., Galán, C., \& Mandrioli, P. (2006). May the definition of pollen season influence aerobiological results? Aerobiologia, 22(1), 13-25. https://doi.org/10.1007/s10453-0059011-x

Kaszewski, B. M., Pidek, I. A., Piotrowska, K., \& WeryszkoChmielewska, E. (2008). Annual pollen sums of alnus in Lublin and Roztocze in the years 2001-2007 against selected meteorological parameters. Acta Agrobotanica, 61(2), 57-64. https://doi.org/10.5586/aa.2008.033 
Kossowska-Cezak, U. (2007). Podstawy meteorologii i klimatologii. Wydawnictwo Szkoły Wyższej Przymierza Rodzin.

Kryza, M., Wałaszek, K., Ojrzyńska, H., Szymanowski, M., Werner, M., \& Dore, A. J. (2017). High-resolution dynamical downscaling of ERA-interim using the WRF regional climate model for the area of Poland. Part 1: Model configuration and statistical evaluation for the 1981-2010 period. Pure and Applied Geophysics, 174(2), 511-526. https://doi.org/10.1007/s00024-016-1272-5

Kryza, M., Werner, M., Dudek, J., \& Dore, A. J. (2020). The effect of emission inventory on modelling of seasonal exposure metrics of particulate matter and ozone with the WRF-Chem Model for Poland. Sustainability, 12(5414), 1-16. https://doi.org/10.3390/su12135414

Kubik-Komar, A., Piotrowska-Weryszko, K., WeryszkoChmielewska, E., Kuna-Broniowska, I., Chłopek, K., Myszkowska, D., Puc, M., Rapiejko, P., Ziemianin, M., Dąbrowska-Zapart, K., \& Lipiec, A. (2019). A study on the spatial and temporal variability in airborne Betula pollen concentration in five cities in Poland using multivariate analyses. Science of the Total Environment, 660(2018), 1070-1078. https://doi.org/10.1016/j.scitotenv.2019.01. 098

Kurganskiy, A., Ambelas Skjøth, C., Baklanov, A., Sofiev, M., Saarto, A., Severova, E., Smyshlyaev, S., \& Kaas, E. (2020). Incorporation of pollen data in source maps is vital for pollen dispersion models. Atmospheric Chemistry and Physics, 20(4), 2099-2121. https://doi.org/10.5194/acp20-2099-2020

Latałowa, M., Miętus, M., \& Uruska, A. (2002). Seasonal variations in the atmospheric Betula pollen count in Gdańsk (southern Baltic coast) in relation to meteorological parameters. Aerobiologia, 18(1), 33-43. https://doi.org/ 10.1023/A: 1014905611834

Majeed, H. T., Periago, C., Alarcón, M., \& Belmonte, J. (2018). Airborne pollen parameters and their relationship with meteorological variables in NE Iberian Peninsula. Aerobiologia, 34(3), 375-388. https://doi.org/10.1007/s10453018-9520-z

Malkiewicz, M., Drzeniecka-Osiadacz, A., \& Krynicka, J. (2016). The dynamics of the Corylus, Alnus, and Betula pollen seasons in the context of climate change (SW Poland). Science of the Total Environment, 573, 740-750. https://doi.org/10.1016/j.scitotenv.2016.08.103

Maya-Manzano, J. M., Skjøth, C. A., Smith, M., Dowding, P., Sarda-Estève, R., Baisnée, D., McGillicuddy, E., Sewell, G., \& O'Connor, D. J. (2021). Spatial and temporal variations in the distribution of birch trees and airborne Betula pollen in Ireland. Agricultural and Forest Meteorology. https://doi.org/10.1016/j.agrformet.2020.108298

Myszkowska, D. (2013). Prediction of the birch pollen season characteristics in Cracow, Poland using an 18-year data series. Aerobiologia, 29(1), 31-44. https://doi.org/10. 1007/s10453-012-9260-4

Myszkowska, D., Jenner, B., Puc, M., Stach, A., Nowak, M., Malkiewicz, M., Chłopek, K., Uruska, A., Rapiejko, P., Majkowska-Wojciechowska, B., \& Weryszko-Chmielewska, E. (2010). Spatial variations in the dynamics of the Alnus and Corylus pollen seasons in Poland. Aerobiologia, 26, 209-221. https://doi.org/10.1007/s10453-010-9157-z
Myszkowska, D., Piotrowicz, K., Ziemianin, M., Bastl, M., Berger, U., Dahl, Å., Dạbrowska-Zapart, K., Górecki, A., Lafférsová, J., Majkowska-Wojciechowska, B., \& Malkiewicz, M. (2021). Unusually high birch (Betula spp.) pollen concentrations in Poland in 2016 related to longrange transport (LRT) and the regional pollen occurrence. Aerobiologia. https://doi.org/10.1007/s10453-021-09703w

Ojrzyńska, H., Kryza, M., Wałaszek, K., Szymanowski, M., Werner, M., \& Dore, A. J. (2017). High-resolution dynamical downscaling of ERA-interim using the WRF regional climate model for the area of Poland. Part 2: Model performance with respect to automatically derived circulation types. Pure and Applied Geophysics, 174(2), 527-550. https://doi.org/10.1007/s00024-016-1273-4

Pasken, R., \& Pietrowicz, J. A. (2005). Using dispersion and mesoscale meteorological models to forecast pollen concentrations. Atmospheric Environment, 39(40), 7689-7701. https://doi.org/10.1016/j.atmosenv.2005.04. 043

Puc, M., Kotrych, D., Lipiec, A., Rapiejko, P., \& Siergiejko, G. (2016). Birch pollen grains without cytoplasmic content in the air of Szczecin and Bialystok. Alergoprofil, 12(2), 101-105.

Puc, M., Wolski, T., Camacho, I. C., Myszkowska, D., Kasprzyk, I., Grewling, Ł, Nowak, M., Weryszko-Chmielewska, E., Piotrowska-Weryszko, K., Chłopek, K., \& DąbrowskaZapart, K. (2015). Fluctuation of birch (Betula L.) pollen seasons in Poland. Acta Agrobotanica, 68(4), 303-313. https://doi.org/10.5586/aa.2015.041

Rapiejko, P., Stankiewicz, W., Szczygielski, K., \& Jurkiewicz, D. (2007). Progowe stężenie pyłku roślin niezbędne do wywołania objawów alergicznych. Otolaryngologia Polska, 61(4), 591-594. https://doi.org/10.1016/S00306657(07)70491-2

R-Core Team. (2019). R: A language and environment for statistical computing. R Foundation for Statistical Computing, Vienna, Austria. https://www.R-project.org/

Samoliński, B., Raciborski, F., Lipiec, A., Tomaszewska, A., Krzych-Fałta, E., Samel-Kowalik, P., Walkiewicz, A., Lusawa, A., Borowicz, J., Komorowski, J., \& SamolińskaZawisza, U. (2014). Epidemiologia chorób alergicznych w polsce (ECAP). Alergologia Polska-Polish Journal of Allergology, 1(1), 10-18. https://doi.org/10.1016/j.alergo. 2014.03.008

Skamarock, W. C., Klemp, J. B., Dudhi, J., Gill, D. O., Barker, D. M., Wang, W., \& Powers, J. G. (2008). A description of the advanced research WRF version 3. Technical Report. https://doi.org/10.5065/D6DZ069T

Skjøth, C. A., Smith, M., Brandt, J., \& Emberlin, J. (2009). Are the birch trees in Southern England a source of Betula pollen for North London? International Journal of Biometeorology. https://doi.org/10.1007/s00484-0080192-1

Skjøth, C. A., Sommer, J., Stach, A., Smith, M., \& Brandt, J. (2007). The long-range transport of birch (Betula) pollen from Poland and Germany causes significant pre-season concentrations in Denmark. Clinical and Experimental Allergy, 37(8), 1204-1212. https://doi.org/10.1111/j.13652222.2007.02771.x 
Skjøth, C. A., Geels, C., Hvidberg, M., Hertel, O., Brandt, J., Frohn, L. M., Hansen, K. M., Hedegaard, G. B., Christensen, J. H., \& Moseholm, L. (2008). An inventory of tree species in Europe-An essential data input for air pollution modelling. Ecological Modelling, 217(3-4), 292-304.

Skjøth, C. A., Baker, P., Sadyś, M., \& Adams-Groom, B. (2015). Pollen from alder (Alnus sp.), birch (Betula sp.) and oak (Quercus sp.) in the UK originate from small woodlands. Urban Climate, 14, 414-428. https://doi.org/10.1016/j. uclim.2014.09.007.

Sofiev, M., Berger, U., Prank, M., Vira, J., Arteta, J., Belmonte, J., Bergmann, K. C., Chéroux, F., Elbern, H., Friese, E., \& Galan, C. (2015). MACC regional multi-model ensemble simulations of birch pollen dispersion in Europe. Atmospheric Chemistry and Physics, 15(14), 8115-8130. https:// doi.org/10.5194/acp-15-8115-2015

Sofiev, M., Siljamo, P., Ranta, H., Linkosalo, T., Jaeger, S., Rasmussen, A., Rantio-Lehtimaki, A., Severova, E., \& Kukkonen, J. (2013). A numerical model of birch pollen emission and dispersion in the atmosphere. Description of the emission module. International Journal of Biometeorology, 57, 45-58. https://doi.org/10.1007/s00484-0120532-z

Sofiev, M., Siljamo, P., Ranta, H., \& Rantio-Lehtimäki, A. (2006). Towards numerical forecasting of long-range air transport of birch pollen: Theoretical considerations and a feasibility study. International Journal of Biometeorology, 50(6), 392-402. https://doi.org/10.1007/s00484-006-0027$\mathrm{X}$

Stach, A., Smith, M., Skjøth, C. A., \& Brandt, J. (2007). Examining Ambrosia pollen episodes at Poznań (Poland) using back-trajectory analysis. International Journal of
Biometeorology, 51, 275-286. https://doi.org/10.1007/ s00484-006-0068-1

Veriankaite, L., Siljamo, P., Sofiev, M., Šauliene, I., \& Kukkonen, J. (2010). Modelling analysis of source regions of long-range transported birch pollen that influences allergenic seasons in Lithuania. Aerobiologia, 26, 47-62. https://doi.org/10.1007/s10453-009-9142-6

Verstraeten, W. W., Dujardin, S., Hoebeke, L., Bruffaerts, N., Kouznetsov, R., Dendoncker, N., Hamdi, R., Linard, C., Hendrickx, M., Sofiev, M., \& Delcloo, A. W. (2019). Spatio-temporal monitoring and modelling of birch pollen levels in Belgium. Aerobiologia, 35(4), 703-717. https:// doi.org/10.1007/s10453-019-09607-w

Werner, M., Kryza, M., \& Wind, P. (2018). High resolution application of the EMEP MSC-W model over Eastern Europe-Analysis of the EMEP4PL results. Atmospheric Research, 212, 6-22. https://doi.org/10.1016/j.atmosres. 2018.04.025

Woś A. (1993). Climatic regions of Poland in the light of the frequency of various weather types. Zeszyty Instytutu Geografii i Przestrzennego Zagospodarowania PAN.

Yamartino, R. J. (1985). Atmospheric pollutant deposition modelling. Chapter 27. In Houghton, D. D., (Ed.) Handbook of applied meteorology (pp. 754-766). A WileyInterscience Publication

Zhang, R., Duhl, T., Salam, M. T., House, J. M., Flagan, R. C., Avol, E. L., Gilliland, F. D., Guenther, A., Chung, S. H., Lamb, B. K., \& VanReken, T. M. (2014). Development of a regional-scale pollen emission and transport modeling framework for investigating the impact of climate change on allergic airway disease. Biogeosciences, 11(6), 1461-1478. https://doi.org/10.5194/bg-11-1461-2014 